\title{
The Diffusion of Strikes: A Dyadic Analysis of Economic Sectors in the Netherlands, $1995-2007^{1}$
}

\author{
Giedo Jansen \\ University of Twente \\ Roderick Sluiter and Agnes Akkerman \\ Vrije Universiteit Amsterdam
}

\begin{abstract}
This study examines the extent to which strikes diffuse across sectors and to what extent this diffusion of strikes can be explained by similarities and interdependencies between sectors. For this purpose, the authors examine a unique temporally disaggregated and dyadic database on strikes in Dutch sectors during the 1995-2007 period. Based on a series of discrete-time event-history models, their study clearly supports the relevance of intersectoral interdependencies to understanding when strikes in one sector are followed by strikes in other sectors. Sector-to-sector labor mobility has a significant and positive impact on the diffusion of strikes across sectors.
\end{abstract}

\section{INTRODUCTION}

Strikes are not isolated events. Industrial action often occurs in waves or cycles and may spread across a country like a forest fire (Biggs 2005). In the literature, the dominant approach to explain why strikes may appear in waves or clusters is that strike patterns are reflections of the business cycle

\footnotetext{
${ }^{1}$ The authors acknowledge financial support from the Conflict and Security program of the Netherlands Organization for Scientific Research, grant 432-08-022. For helpful comments on earlier versions of this article, we wish to thank the AJS reviewers. Direct correspondence to Giedo Jansen, University of Twente, Institute for Innovation and Governance Studies, P.O. Box 217, 7500 AE Enschede, the Netherlands. E-mail: giedo.jansen @utwente.nl
}

(C) 2016 by The University of Chicago. All rights reserved.

0002-9602/2016/12106-0006\$10.00 
and the bargaining rhythm: strike waves follow changes in production, labor markets, and bargaining relations (Franzosi 1995; Brandl and Traxler 2010; Vandaele 2011). An alternative explanation, however, has received far less attention: the diffusion of strikes. To explain the spatial and temporal clustering of events and behavior, a rapidly increasing number of studies in the social and political sciences are examining processes of diffusion (cf. Strang and Soule 1998; Elkins and Simmons 2005). Diffusion or contagion effects have been used to explain a wide range of phenomena, including patterns of policy adoption (Berry and Berry 1990; Volden 2006; Sluiter 2012), organizational founding (Hedström 1994), waves of sit-ins (Andrews and Biggs 2006), street protests (Jung 2010), riots (Myers 2010), and more violent forms of conflict (Holden 1986; Hegre et al. 2001; Gleditsch 2007; Buhaug and Gleditsch 2008; Schutte and Weidmann 2011).

With respect to industrial conflict and labor protest, only a few studies have investigated whether contagion or diffusion occurs and to what extent the outbreak of a strike may stimulate further strike activity. Conell and Cohn (1995) examined strikes in French coal mines in the 1890-1935 period, and Biggs (2005) investigated strike patterns in late 19th-century Chicago and Paris. Conell and Cohn suggest that strikes transmit information that stimulates mobilization elsewhere. These authors conclude that temporal clustering of industrial action occurs because workers in one location learn about other people's grievances, demands, strategic opportunities, and bargaining conditions. The notion that industrial action propagates from one group of workers to another is also found in a study by Biggs (2005). He suggests that strikes are inspirational for others because they create momentum for workers deciding when to start a strike, and they shape expectations of success. Biggs finds that strike waves are characterized by a power law distribution, or a "forest fire model," in which a strike is likely to spread to more firms when a large number of firms are already involved.

In this article, we study the diffusion of strikes in the Netherlands. In doing so, we make three contributions to the literature. First, the few existing studies on strike diffusion provide evidence for the temporal and spatial diffusion of strikes (Conell and Cohn 1995; Biggs 2005), but they pay relatively little attention to what conditions this diffusion. In the current study, we will use diffusion theories to formulate hypotheses on the conditions under which one strike is followed by the next. As diffusion theories dictate, we specifically investigate the effects of similarities and interdependencies between the actors or units involved. We test our hypothesis on the conditions of strike diffusion using data on the Netherlands for the period 1995-2007. In doing so, this study provides a strict test case for the general claim that the occurrence of one strike increases the probability of another. Compared to other advanced economies, strikes are relatively rare in the Netherlands. If the dif- 
fusion of strikes occurs in this setting, we would expect this phenomenon to be even more pronounced in more strike-prone contexts.

Second, we analyze the diffusion of strikes using an event-history approach. Event-history analysis has been suggested to be the most appropriate method for analyzing protest events and the diffusion of collective action (Olzak 1989; Jung 2010). One of the merits of event-history analysis is that it does not require temporal aggregation and therefore retains exact information on the timing of each action. Event-history techniques have been widely used in the protest and conflict literature to explain the diffusion of collective action (Myers 1997, 2000, 2010; Soule 1997, 1999; Olzak, Beasley, and Olivier 2002; Andrews and Biggs 2006; Braun and Koopmans 2010). In strike research, however, most published strike statistics are aggregated to annual totals, making it impossible to determine the exact timing of strikes. The historical data used by Conell and Cohn (1995) and Biggs (2005) are rare exceptions of data sources on industrial conflict disaggregated to daily time series. The temporally disaggregated data on the Netherlands that we use for our eventhistory analysis are virtually unparalleled as they provide detailed day-to-day statistics on strikes for a relatively long period. Moreover, the availability of several secondary data sources allows for a combination of time-varying, unit-specific variables explaining strikes, with relational variables between units to assess the conditions of strike diffusion.

Finally, the scope of our study covers nearly all areas of economic activity. Instead of focusing on diffusion within a single industry, such as the mining sector (Conell and Cohn 1995), we examine the diffusion of strikes across sectors. In the literature, the notion of strike diffusion often entails the assumption that strike waves occur because workers are inspired by others, including strikers in other industries and in other economic activities (Shorter and Tilly 1974; Cronin 1979; Franzosi 1995). An example of this phenomenon in the U.S. labor relations context is the 2014 strikes and labor actions of Wal-Mart employees, who were inspired by the strikes of fast-food industry employees, with respect to both the wage demands and the means of protesting, "borrow[ing] several publicity-winning ideas from the fast-food movement" (Tabuchi and Greenhouse 2014, para. 14). Another recent example, from the Dutch context, is the protest actions of academic personnel in Amsterdam against university budget cuts, which were directly inspired by a large strike in the Dutch cleaning industry. In a union magazine, one of the university's protest leaders specifically declared that they "got carried away by the militant attitude [of the cleaners on their campus]" and that they "learned a lot from their ways of protesting" (Aklalouch 2014, para. 4). While both examples illustrate that strikes spread from one sector to another, there is little systematic empirical evidence for the extent to which a strike in one sector stimulates strike incidence in other sectors. 
In sum, this study examines the extent to which strikes diffuse across sectors and to which the diffusion of strikes across sectors can be explained by similarities and interdependencies between sectors. For this purpose, and using several sources of time-varying and relational information on Dutch industries, we construct a sector dyad period file, a "stacked" data matrix in which the sector dyads (i.e., the pairs of two sectors), observed at a daily interval, are the units of analysis. By formally measuring and modeling the effects of these sector-to-sector linkages on the temporal clustering of strikes, we answer the following central question: To what extent do strikes diffuse across sectors and to what extent is the diffusion of strikes across sectors conditioned by similarities and interdependencies between sectors?

\section{DIFFUSION THEORY AND STRIKES}

The core argument of diffusion studies in the social movement, protest, and conflict literature is that events do not occur in isolation and the occurrence of one event affects the probability of the occurrence of another. By implication, diffusion processes require that the actors or units under study constitute a social system that "channels" diffusion (Rogers 1995). Actors are assumed to respond when those to whom they are socially connected adopt a trait or practice (Strang 1991). On the basis of the diffusion literature, we consider two general mechanisms through which actors influence each other: learning by information spillover and adaptation by interdependency (Elkins and Simmons 2005). Diffusion via learning implies that the initial action provides information about the consequences of that action and the conditions under which it occurred and that other actors use this information to assess the costs and benefits of adopting the same action in their own situation. From this perspective, strikes stimulate new strikes because workers in one location learn about the grievances, demands, strategic opportunities, and bargaining conditions elsewhere. Diffusion via adaptation occurs when the initial action changes the conditions under which new actions take place, creating externalities for other actors. From this perspective, strikes diffuse across time and place because a strike in one location can then affect production and working conditions in other firms and sectors. As we discuss below in more detail, both mechanisms lead us to expect that there is a relationship between the occurrence of a strike in one sector and the probability of a strike in another. In the next sections, we elaborate on the conditions under which these proposed diffusion mechanisms may occur.

\section{Diffusion by Learning}

The first mechanism underlying the processes of diffusion is that actors in one location or at one moment may learn from the actions of others at another 
place or time. The notion that protest strategies and repertoires can be learned from others can be found, for example, in McAdam's (1995) discussion of the interplay between "initiator movements," such as Solidarity in Poland or the American civil rights movement, and the "spinoff movements" that draw their inspiration from the initiators. Other examples of the diffusion of protest tactics include the development of student protests in the United States in the 1980s (Soule 1997), the mobilization of workers in the 1969 "autonno Caldo" (Franzosi 1995), and the global spread of suicide protests in the 20th century (Biggs 2013). For a more extensive overview of the role of learning in the diffusion of social movements, see Givan, Roberts, and Soule (2010) and Wang and Soule (2012).

Diffusion by learning has also been applied to explain the temporal and spatial clustering of industrial conflict. The assumption that workers learn from the prior actions of others is prominent in Conell and Cohn's (1995) study of the diffusion of strikes in French coal mines. They discuss three possible ways in which learning occurs. The common argument in these explanations of why strikes may stimulate further worker mobilization is that they involve some form of information transfer. First, these authors assume that labor protest raises workers' consciousness by making them aware of new potential grievances. News about strikes elsewhere can start the discussion on working conditions at the workplace and can transform latent complaints into concrete and articulated demands. Second, they argue that prior strikes function as an occasion for protest. Workers often need an arbitrary date to represent a focus point for collective action. Therefore, strikes, like the ritualized May Day protests, "serve to notify the rest of the labor movement that the time to strike is now" (Conell and Cohn 1995, p. 369). Finally, strikes are assumed to provide tactical guidance. Conell and Cohn argue that other workers' protests provide information on the relative strength of workers and authorities and on the tactical opportunities in parallel settings.

Theories on learning often stipulate that the mere availability of information is not sufficient to cause the imitation of a certain practice; instead, learning from other people's actions would be conditional on the degree of proximity or similarity between the actors or units involved. In the literature, proximity is usually conceptualized in spatial or geographical terms. Spatial proximity is assumed to ease interactions between actors and to provide "the best summary of the likelihood of mutual awareness and interdependence" (Strang and Soule 1998, p. 275). Similarity is normally understood in terms of shared characteristics and may function as an indicator of proximity in a social sense, as the reverse of social distance (McAdam and Rucht 1993; Strang and Meyer 1993; Strang and Tuma 1993; McAdam, Tarrow, and Tilly 2001; Braun and Koopmans 2010). The idea is that information transmitted by prior actions elsewhere is more readily accessible, relevant, and easily interpreted if the units are more closely located to each other or share 
similar characteristics (Agrawal, Kapur, and McHale 2008). Studying U.S. student protests in the 1980s, Soule (1997) showed that protest strategies diffuse most rapidly among campuses with similar structural characteristics, such as endowment levels and prestige rankings. With respect to the diffusion of ethnic conflict, Braun and Koopmans (2010) found that violent behavior against immigrants in Germany in the 1990s was more likely to spread across counties that shared similar political, socioeconomic, and demographic structures, such as the level of right-wing party support, the amount of agrarian employment, and the percentage of immigrants.

In this study, we build on the idea that proximity fosters diffusion by learning. In doing so, however, we will not consider proximity in spatial terms. Examining spatial proximity would require a different research design with different units of analysis. Sector dyads, the units of analysis in the current study, cannot be linked to a specific geographical location. None of the sectors under study is restricted to a specific region in the Netherlands, let alone to a specific municipality or city. Rather than focusing on spatial proximity, we therefore focus on social proximity. For clarity, we will refer to social proximity as similarity for the remainder of this study. In the current research setting, similarity entails the characteristics of sector dyads (i.e., the similar features of two sectors in a pair) that advance information spillover about strikes.

Information about strikes may be transmitted via communication through the social network of actors (e.g., employees, strikers, management, and professional negotiators) involved in the strike in one sector and the actors working in another sector (or actors involved in upcoming wage negotiations in that sector). For example, a union negotiator in the construction sector may discuss a strike with his colleague who prepares negotiations for the manufacturing sector; alternatively, a worker from the manufacturing sector meets actors from the transport sector during professional interaction (e.g., day-today professional encounters or occupational courses and networks, such as business meetings or director interlocks [Burt 1983] and professional associations or unions). In addition to interaction in work-related networks, employees may exchange information about the strike during private interactions, such as during leisure activities or family gatherings (Gould 1991).

The probability of such social interaction in, and the diffusion of information through, social networks, and thus the exchange of information about a strike, increase when the workers of two sectors share more similarities with respect to their occupation, skills, and level of education (Marsden 1988; Schneider et al. 1997; McPherson, Smith-Lovin, and Cook 2001). Information on bargaining outcomes elsewhere, including strikes, may be more relevant and more easily interpreted for workers, negotiators, and management when they take place in sectors with similar skill levels. It is important 
to note, however, that the channels of information spillover are not exclusively relational (or dyadic) in nature. For one, information on a strike (e.g., about the union's demands and strategy, the employer's response, and employees' level of militancy) may be transmitted via mass media. The visibility of a strike via the media probably depends on the size of the firm, the participation rate, and the societal and economic impact of the strike. Massive protests are more likely to draw (national) media attention compared to smaller protests (Myers 2000). It is likely that workers at a firm in sector A may learn about what is going on in sector B through these "nonrelational" channels. Similarity plays a role here, too. When employees are more similar, the information provided by mass media is more relevant, and workers can more easily interpret information when it involves strikers who resemble them. Recent research on the Netherlands has confirmed that during collective bargaining, negotiators also tend to consider similar settings and parallel bargaining situations for comparisons (Lehr, Akkerman, and Torenvlied 2014). Similar actors serve as a reference group, for instance, for normative guidance (Marsden and Friedkin 1993; Passy and Giugni 2001; Diani 2004; Centola and Macy 2007; Lim 2008). In this respect, the so-called threshold models of collective behavior (Granovetter 1979; Centola and Macy 2007 ) stipulate that workers - even if they already possess the necessary information on protest strategies and repertoires - may be willing to strike only if they witness others striking first. Employees probably relate more to the grievances and demands of others when these other employees (potentially with a lower threshold for collective action) are more similar to them, for instance, with regard to occupation and skill level. Hence, the core proposition based on diffusion by learning is that industrial conflict is more likely to spread from one sector to another when the occupational structure of the two sectors is more similar:

Hypothesis 1.-A strike in one sector is more likely to stimulate the occurrence of a strike in another sector when these sectors have a more similarly skilled workforce.

\section{Diffusion by Adaptation}

An alternative explanation for diffusion, adaptation, does not prioritize information spillover as the key mechanism for diffusion. Adaptation occurs when the initial action creates externalities for other actors and changes the conditions under which other actors operate. A prerequisite for diffusion through adaptation is that actors are somehow interdependent. Elkin and Simmons (2005, p. 42), for example, mention adaptation to altered conditions as a driving mechanism in the diffusion of government decisions. One country's adoption of liberal policies to enhance its competitiveness disrupts the competitive balance for other countries. Consequently, they argue that 
policies may diffuse as other countries are pressured to adapt by adopting similar policies. Another example is the contagious effect of civil wars. Buhaug and Gleditsch (2008, p. 221) describe how civil war in one country changes the welfare in neighboring countries through a sudden influx of refugees, thereby creating strain and stimulating new conflict by increasing competition for resources in the host countries.

From this perspective, strikes may diffuse because a strike in one sector may subsequently disrupt the production process or service delivery in other sectors (Perrone, Wright, and Griffin 1984). As for diffusion by learning, similarity and proximity shape the degree of interdependency between sectors and therefore affect the likelihood that the labor or product market conditions in one sector are affected by a strike in another sector. Proximity in the chain of production may increase the degree to which a change in wages in one sector affects the price of production factors in the other sector (cf. "positions in the system of economic interdependencies" in Perrone et al. [1984, p. 413]). Economic interdependencies in the production or service delivery process are believed to be stronger with larger financial flows, that is, the supply and acquisition of goods and services (often assessed in so-called input-output tables; cf. Mizruchi and Koenig 1986). Especially in the short run, a strike in one sector can disrupt production in the other firms or sectors in the chain of production, for instance, when the strike hinders the trade of input materials to the firm(s) on strike. When the production or delivery of materials is disrupted by the strike (Perrone et al. 1984), it can cause problems in other firms, for example, with their ability to maintain current wages or employment, which in turn may lead to labor strikes in these "affected" firms. Hence, the first proposition based on adaptation is that industrial conflict is more likely to spread from one sector to another when the production or service processes of the two sectors are more interdependent.

Hypothesis 2.-A strike in one sector is more likely to stimulate the occurrence of a strike in another sector when the degree of interdependence in the production or service delivery process between these sectors is higher.

Another plausible consequence of a strike is that its outcomes change employment in a firm, and subsequently in the (proximate) sectors, via labor market competition. Standard labor economic principles explain why changes in employment may cause conflict to spread. A successful strike may increase the price of labor, for example, when unions are able to negotiate higher wages for their members. Such changes in the price of labor cause a lower demand for labor (for instance, when management decides to invest in technology to replace manual or administrative labor). Those unemployed in the more costly sectors will seek employment in other sectors, affecting the supply of labor in the "receiving" sector. Alternatively, in a tight labor market when labor is scarce, favorable outcomes from a strike may increase employees' wage demands in other sectors as well. In the aforementioned 
Wal-Mart example (Tabuchi and Greenhouse 2014), the employees' protest resulted in an increase of their wage above the federal minimum wage, which itself is expected to produce a ripple effect and affect wage demands in sectors that compete for the same workers as Wal-Mart, such as health care, child care, and restaurants (Krugman 2015; Morath 2015; Neate 2015). Hence, because (expected) changes in labor market conditions affect wage demands in negotiations (Kaufman 1984; Kaufman and Woglom 1984), strikes may also diffuse via the effect they have on labor market conditions. ${ }^{2}$

This form of interdependency between sectors is caused by labor market competition and is driven by similarity-in this case, similarities in the labor force. Whether changes in wages lead to wage competition between sectors as well as the (threat of) workers migrating to higher wages depends on the degree to which the sectors employ similarly skilled workers. Workers who have skills that are usable in both sectors are likely to make transfers relatively easily from one sector to the other. Hence, for sectors in which employees share educational and occupational backgrounds, changes in wages in one sector, which change the demand for labor in that sector, more easily affect the supply of labor in the other sector (Cörvers and Heijke 2004; Kaufman 2007). Therefore, a second proposition based on adaptation is that industrial conflict is more likely to spread from one sector to another when labor market competition between the two sectors is stronger.

HypotHesis 3. - A strike in one sector is more likely to stimulate the occurrence of a strike in another sector when the degree of labor market competition between these sectors is higher.

\section{STRIKES IN THE NETHERLANDS}

We test our hypotheses in the empirical context of the Netherlands. The Netherlands is generally considered to be a low-strike country. Together with countries such as Germany, Switzerland, and Austria, it has among the lowest number of lost working days due to strikes in Europe (Piazza 2005; Vandaele 2011). Yet, strikes are not absent in the Netherlands. For researchers interested in the frequency of strikes in the Netherlands, there are two series of statistics available that provide information over a long period (Van Cruchten, Kuijpers, and Van der Velden 2006). The first is the Strike Statistics series (Statistiek Werkstakingen) of Statistics Netherlands (CBS). These national records are used by the International Labor Organization to construct harmonized strike statistics for international compar-

\footnotetext{
${ }^{2}$ Such effects on labor market conditions may also set in after wage increases due to wage bargaining without a strike. However, conflict over wages often arises as a result of changes in economic factors causing uncertainty in negotiations (Shalev 1980). In such situations, strikes are a prelude to the first event in the adaptation of changes in the price of labor.
} 
isons. The second is the database Strikes in the Netherlands (Stakingen in Nederland, abbreviated here as SIN) compiled by Dutch historian Sjaak Van der Velden. Both series show similar trends with respect to the aggregate annual numbers of strikes or working days lost over recent decades (Van Cruchten et al. 2006). However, in all years under study, the number of reported strikes in the SIN database is larger than that in the CBS strike series (see fig. 1).

Van Cruchten et al. (2006) have noted that differences between CBS and SIN data arise from differences in the timing of the data collection and the sources and definitions that are used. Compared to the CBS series, the SIN database is based on a wider scope of sources (e.g., not limited to reports by the Netherlands National News Agency) and a somewhat broader definition of strikes (e.g., not limited to strikes that lead to a loss of production). For this study, however, the most compelling reason to use the SIN database instead of the CBS series is the availability of information on the exact timing of strikes and the companies involved in each strike. Because legal regulations prevent Statistics Netherlands from publishing information on individual strikes, the SIN database is the only available data source that is appropriate for studying the temporal clustering of strikes across sectors. For a more elaborate comparison of the two series, we refer to Van der Velden (2000, 2007), Van der Bie (2001), and Van Cruchten et al. (2006).

On the basis of quarterly aggregated SIN data, there is considerable variation in the frequency of strikes across sectors and time (see fig. 2). In the period under study, the manufacturing sector (132 strikes) and the transport and communication sector (147 strikes) were the most strike-prone areas of economic activity in the Netherlands. The fewest strikes occurred

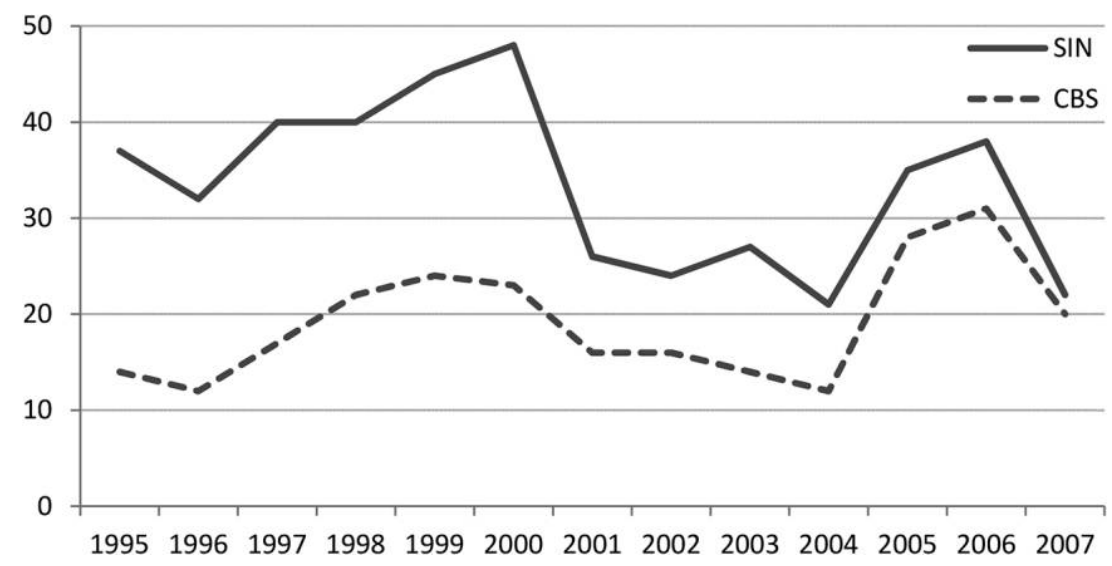

FIG. 1.-Annual strike frequency in the Netherlands based on CBS and SIN data, 1995-2007. Source for CBS data is Statline (Statistics Netherlands 2013); source for SIN data is Strikes in the Netherlands (2011). 

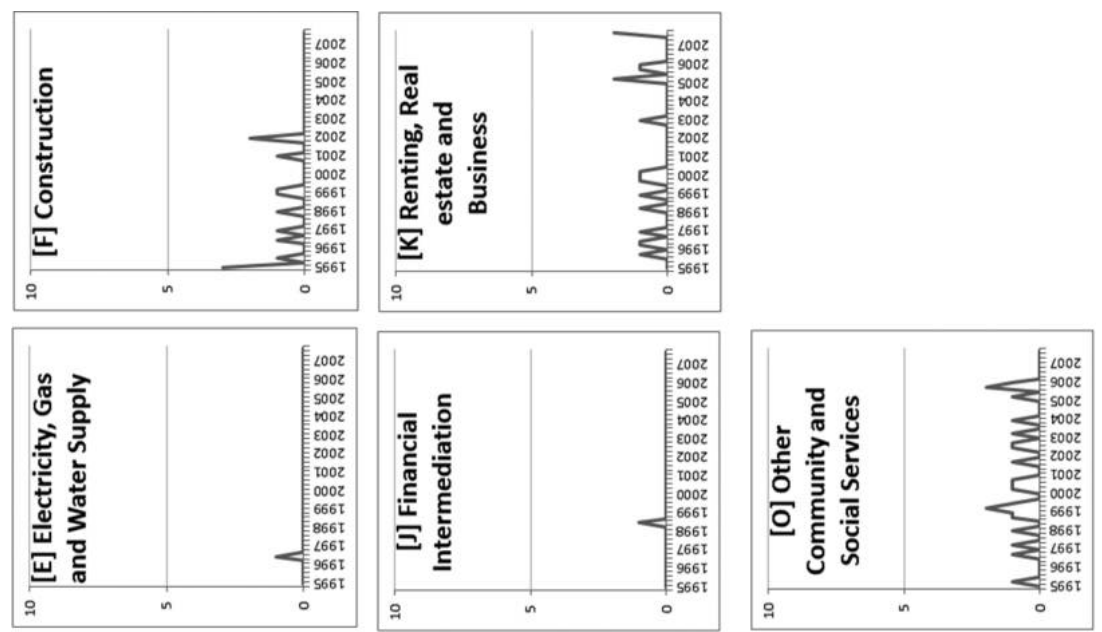

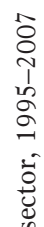
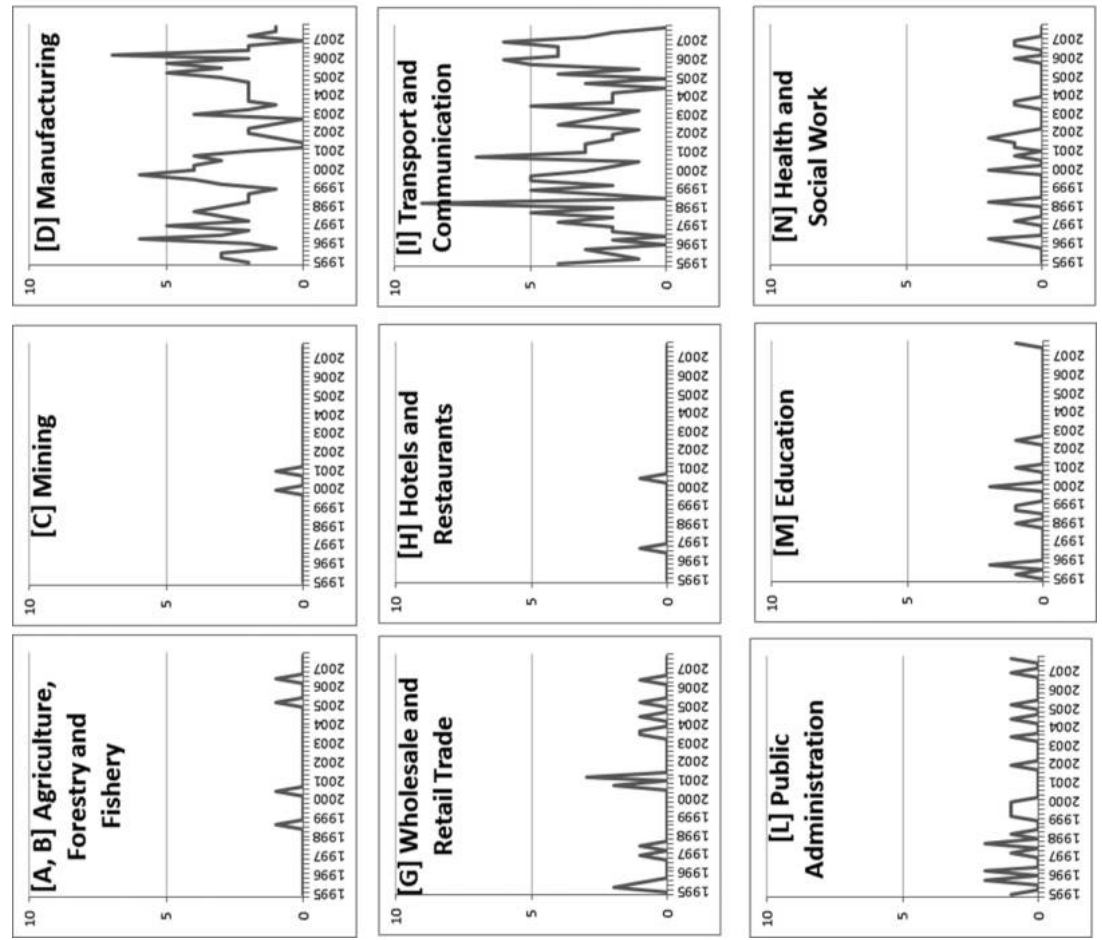

This content downloaded from 131.174.168.014 on January 17, 2017 04:17:01 AM All use subject to University of Chicago Press Terms and Conditions (http://www.journals.uchicago.edu/t-and-c). 
in the financial sector and in the energy and water supply sector (one strike each). The total quarterly number of strikes in the Netherlands varied during the period under study between 3 and 15. Typically, multiple sectors experience strikes around the same time. In almost all quarters during 19952007 , strikes occurred "concurrently" in at least two (and, on average, three to four) different sectors. On two occasions (2000/Q1 and 2005/Q2), half of the sectors under study experienced strikes during the same quarter. This type of temporal clustering of strike events across sectors is examined in this study.

\section{DATA AND MEASURES}

\section{Sector Dyad Period File}

To test our hypotheses empirically, we make use of various data sources that we compiled into a new data file. This file, labeled the Sector Dyad Period File of Strikes in the Netherlands, 1995-2007 (SDPF-SIN), is a database providing information on strike events in Dutch economic sectors. The file covers 14 economic sectors in the Netherlands, defined on the basis of the Dutch SBI-93 (Standaard Bedrijfsindeling 1993). The SBI-93 classification is comparable to the international NACE divisions (rev. 1) of the European Commission. The file includes all economic sectors except SBI/NACE section $\mathrm{P}$ (private households with employed persons) and section Q (extraterritorial organizations and bodies), for which not all statistics are relevant or available.

Information on the exact timing of strikes in the Netherlands is adopted from Van der Velden's SIN database. ${ }^{3}$ The SIN database, archived by the International Institute of Social History in Amsterdam, contains systematic information on no fewer than 16,000 strikes and lockouts, mainly in the 1810-2007 period. For the current data set, only strike actions after January 1, 1995, are taken into account. However, the SDPF-SIN is not simply a subset of the SIN database. A combination of three characteristics makes it an unusual standalone database that enables the investigation of the diffusion of strike events across sectors over time: (1) on the basis of detailed new coding, it links the starting dates of more than 400 strike actions to specific one-digit SBI-93 sectors; (2) the file combines a dyadic structure with a period structure in which sector dyads (combinations of sectors) are the main units of analysis; and (3) information on the exact timing of strikes in sectors is merged with a wide range of other time-varying monadic and dyadic information on Dutch economic sectors.

\footnotetext{
${ }^{3}$ The database Strikes in the Netherlands, an updated version of the database accompanying the similarly named book (Van der Velden 2000), was retrieved from the collaborative webpage of the International Institute of Social History, available at https:// collab.iisg.nl/web/labourconflicts/strikes-in-the-netherlands (accessed May 20, 2011).
} 
Structure of the Data Set

The diffusion of strikes across sectors is examined using a directed-dyad approach (Volden 2006). The dyadic structure of the file implies that neither strike actions nor sectors are the units of analysis. Instead, the main units of analysis are sector dyads between two sectors, here denoted as sector A and sector B. These dyads are observed on a daily interval during the 19952007 period. To account for the direction of diffusion, each pair of sectors is included in the data file twice daily (e.g., the manufacturing sector may influence construction and vice versa). The data set thus includes information for 182 (i.e., $14 \times 13$ ) combinations of sectors per day. Hence, the analysis is based on 182 dyads over a 13-year period with 365 (or 366 in leap years) daily observations per year. The total number of observations in the database, used in all models, is 864,136.

\section{Dependent Variable: Strike in Sector A}

We use a binary dependent variable measuring whether a strike began on a specific day in sector A. If a strike lasts multiple days, only the first day is defined as the event day. Moreover, and following Conell and Cohn (1995), strike relays or other broader (union) campaigns consisting of multiple events around the same issue or following a single strike call are treated as a single strike, for which the timing is defined on the basis of the first day of the first action. The original SIN database contains information on the companies involved in each action. On the basis of the companies involved, each action is assigned a one-digit SBI-93 sector code. In the period under study, 23 strikes appeared to be unclassifiable, occurred in the social employment branch (Wet sociale werkplaats), or involved the refusal of work by inmates (prisoners' strikes). Such events could not be linked to a specific economic sector and were therefore discarded when constructing the strike variable. Moreover, there were 28 strikes for which the exact date is unknown in the original SIN database (three with missing information on the exact month and 25 with missing information on the exact day). For 11 of 28 strikes, the exact starting date was retrieved from newspaper sources using LexisNexis Academic. In total, 402 separate strike events were included in the analysis. Descriptive statistics on the dependent variable and the independent variables are presented in table 1.

\section{Independent Variable: Strike in Sector B}

To examine whether the occurrence of a strike in sector A is affected by the occurrence of strikes in other sectors, our first independent variable is Strike in Sector B. For each day in a sector dyad, this variable measures the strike volume in sector B in the preceding period. First, strike volume 


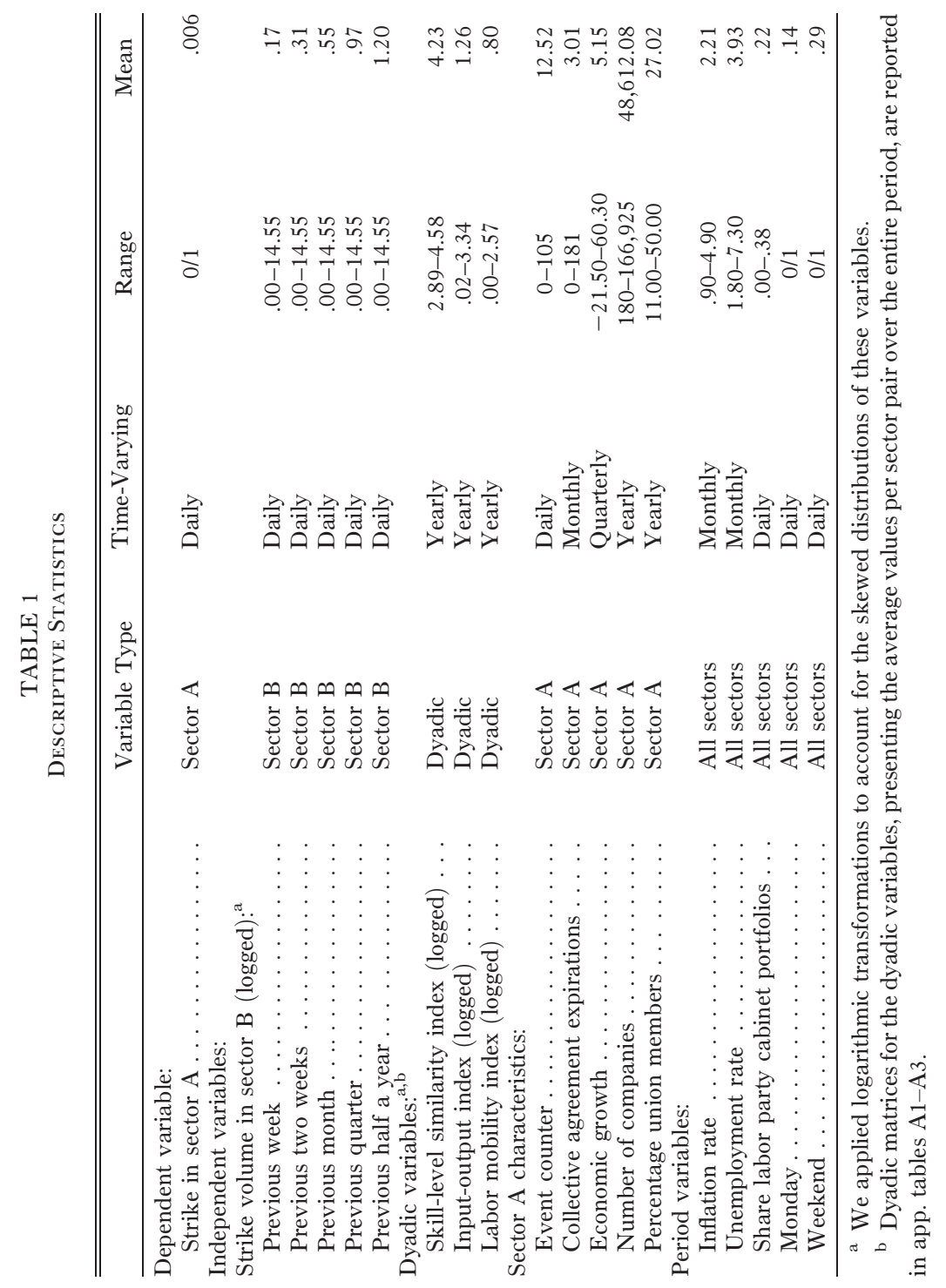

This content downloaded from 131.174.168.014 on January 17, 2017 04:17:01 AM All use subject to University of Chicago Press Terms and Conditions (http://www.journals.uchicago.edu/t-and-c). 
(i.e., the product of the number of strikers and the duration of the strike in days) is taken to account for the fact that some strikes are more visible because of their size and media coverage. Both numbers are retrieved from the SIN database. In the period under study, approximately half of the strikes in the SIN database are estimated to last less than a day. For these strikes, duration is coded as half a day (0.5). For 68 strikes in the period under study, the SIN database did not contain estimates on the number of strikers. In 17 of these cases, we were able to find reports on the number of strikers in newspaper sources using LexisNexis Academic. In the remaining cases, for which information on the number of strikers is missing, strike volume is exclusively based on duration. Second, the preceding period is defined as various durations (i.e., the previous week, two weeks, month, quarter, and the last half year). With these five alternative operationalizations or "incubation periods," we test various durations for the potential effect of strike volume in sector B on the likelihood of a strike in sector A. Precautions are taken to eliminate potential sectoral clustering, that is, the effects of preceding strikes in sector A itself. We therefore include strike volume in sector B only when no other strike took place in sector A during the designated period.

\section{Dyadic Variables}

Most diffusion studies distinguish between "diffusion variables," which are related to the ties between actors, and "intrinsic variables," which are related to all internal characteristics of individual actors that "increase or decrease their propensity to adopt, irrespective of the behavior of others" (Myers 2000, p. 180). The focus of this study is on the relational variables - or, more specifically, the dyadic variables - that may be associated with the clustering of strike events across sectors. The diffusion hypotheses are tested by including three dyadic variables that provide annual information on the linkages between sectors. The first dyadic variable is a skill-level similarity index. Social network research consistently finds that homophily in education level is an important predictor for the creation of social ties among alters (e.g., Marsden 1988; Kalmijn 1998; McPherson et al. 2001) and therefore for social interaction. This variable measures the extent to which the distribution of jobs with different skill levels in sector A corresponds with the distribution in sector B. Following the Standard Classification of Occupations 1992 (SBC92) of Statistics Netherlands (2001), we distinguish between five different skill levels: elementary-skilled occupations, lower-skilled occupations, middle-skilled occupations, higher-skilled occupations, and academic-skilled occupations. Sector-level information on the distribution of these categories of occupations is derived from aggregated information from the Dutch Labor Force Survey 1995-2007 (Enquête Beroepsbevolking). To measure similarity 
in skill level, we compare for each skill level the percentage of the sector A workforce and of the sector B workforce with such jobs. The index is calculated as follows:

Skill-Level Similarity Index

$=100-\left[\frac{\sqrt{(\text { Elementary A-Elementary B })^{2}}+\ldots+\sqrt{(\text { Academic A-Academic B })^{2}}}{2}\right]$.

The second dyadic variable, an input-output index, expresses the degree of interdependence in the production or service delivery processes. This index indicates all financial transactions between sector $\mathrm{A}$ and sector $\mathrm{B}$ (input of sector A from B and output of A to B and vice versa) relative to the total input and output of both sectors. These annual figures are based on the financial relations between sectors in millions of euros in producer prices. We derived this information from the input-output tables published by Statistics Netherlands for the 1995-2007 period. All numbers are taken from the input-output tables based on the SBI-93 sector classification except for the dyads including public administration (L) and education (M). In the SBI-93 classification, input/output figures are not separately available for sectors $\mathrm{L}$ and $\mathrm{M}$. Therefore, a more recent two-digit version of the input/output tables, SBI-2008 (Standaard Bedrijfsindeling 2008), was used to proxy and disentangle the numbers for the public administration dyads and education dyads. The index is calculated as follows:

$$
\text { Input-Output Index }=\frac{(\text { input } \mathrm{AB}+\text { output } \mathrm{AB}) \times 2}{(\text { total input } \mathrm{A}+\text { output } \mathrm{A})+(\text { total input } \mathrm{B}+\text { output } \mathrm{B})} \times 100 \text {. }
$$

The third variable is an indicator of the degree of labor market competition between sectors. On the basis of the assumption that changes in labor market conditions in one sector are more likely to affect the supply of labor in the other sector when employees can more easily shift jobs between the two sectors, the degree of intersectoral labor mobility can be used to express the degree of labor market competition. The labor mobility index is based on estimates of the total number of job changers (in thousands) from sector $\mathrm{A}$ to $\mathrm{B}$ (changes $\mathrm{AB}$ ) and from sector B to A (changes BA). These annual numbers are calculated on request by the Centre for Policy Related Statistics of Statistics Netherlands on the basis of the Dutch Labor Force Survey 1996-2007. For privacy reasons, Statistics Netherlands does not report changes lower than 1.5. Hence, for the majority of the year dyads (73\%), we know that the degree of labor mobility is very low, that is, fewer than 1,500 individuals. We also know the total number of changes in sector A 
and sector B (to any sector) and the total workforce size of sectors. As an approximation, we therefore imputed the changes below 1.5 relative to the sector size and the total changes in sectors $\mathrm{A}$ and sector $\mathrm{B}{ }^{4}$

$$
\text { Labor Mobility Index }=\frac{\text { changes AB }+ \text { changes BA }}{\text { workforce } \mathrm{A}+\text { workforce B }} \times 1,000 \text {. }
$$

\section{Sector A Variables}

To avoid overestimating the diffusion effect on the temporal clustering of strikes, we account for various "intrinsic" — or sector A-specific_-variables with respect to changes in the labor market or the business and bargaining cycle. By including variables for sector A, we account for sector-specific developments in the business and bargaining cycle that may affect the probability of a strike event.

First, a daily varying event counter variable is included, defined as the cumulative number of strike events in sector A over the last five years (going back to January 1, 1990). The event counter is included to control for differences in the strike proneness of sectors (Beck, Katz, and Tucker 1998).

Second, we account for the monthly total number of collective agreement expirations. Expiration dates are derived from the Database of Collective Agreements in the Netherlands (2009) from the Amsterdam Institute for Advanced Labour Studies and supplemented with information from the Dutch Ministry of Social Affairs and Employment. The expiration of a collective agreement usually constitutes the start of negotiations for a new collective agreement. Although these negotiations can begin months before the expiration of the contract, most collective agreements in the Netherlands contain a "no-strike" clause (Visser 1998, p. 306). In principle, this clause commits a union to refraining from industrial action for the duration of the contract. Thus, the expiration of the contract constitutes the first "opportunity to strike" (Kaufman 1982, pp. 476-77).

Third, we control for economic growth, measured as the change in the gross value added (in basic prices) relative to the same quarter of the pre-

\footnotetext{
${ }^{4}$ For these dyads, we estimated the number of changes $\mathrm{AB}$ based on the total number of changes from sector A to any other sector and the total number of changes from any other sector to sector B. We first calculated the total number of changes from A to any other sector that was not accounted for by the other sector A dyads. Because the number of changes was, in all cases, not reported for multiple sector A dyads, we then distributed this estimated remainder among the sector A dyads with missing values. This was done by ratio: if sector B had a relatively large workforce, it was assigned a number of changers from sector A that was proportionally higher. Estimates for 1995 were extrapolated on the basis of a linear trend for the 1996-2000 period. The index expressed all job changes between sectors $\mathrm{A}$ and $\mathrm{B}$ relative to the size of the active workforce of both sectors in thousands (i.e., workforce A, workforce B).
} 
vious year. We derived this information from the quarter accounts of the Dutch macroeconomic indicators published by Statistics Netherlands. Economic growth tends to increase labor power and therefore is generally positively associated with strikes (Brandl and Traxler 2010).

Fourth, we control for sector size and include the annual total number of companies in sector A. This variable measures the absolute number of companies in sector A. Information is retrieved from the annual accounts of the macroeconomic indicators published by Statistics Netherlands. The rationale is that larger sectors, with more firms, are at greater risk of experiencing a strike than smaller sectors with fewer firms.

Fifth, we include the annual percentage of union members in sector A because union density has often been linked to a greater strike probability (Shorter and Tilly 1974; Snyder 1975; Kaufman 1982; Jansen 2014). This variable is measured as the membership of employees ages 15-64 who work at least 12 hours per week. The numbers are calculated by the Centre for Policy Related Statistics of Statistics Netherlands and are based on the Dutch Labor Force Survey 1995-2007. Statistics Netherlands does not distinguish between employees working in mining and quarrying $(\mathrm{C})$ and those working in the manufacturing sector (D). Hence, the annual organization rates in both sectors are assumed to be identical.

\section{Period Variables}

The final set of variables includes non-sector-specific variables to account for the fact that under some circumstances, the likelihood of a strike may increase or decrease for all areas of economic activity simultaneously. Two variables pertain to the national economic situation: the monthly inflation rate and the unemployment rate. Both are obtained from Statistics Netherlands. Another national condition relates to the political situation. Power resource theories predict that the presence of left-wing parties in government should decrease strike activity by shifting industrial conflict from the workplace to the political arena (Korpi and Shalev 1979). The presence of left-wing parties in government is calculated here as the share of cabinet portfolios held by the PvdA, the Dutch Labor Party. Finally, we include two dummy variables for Mondays and weekends to capture the start and end of weekly work schedules and to reduce a potential Monday bias caused by the fact that strike information, like other protest event data, is partially based on newspaper sources (Koopmans and Rucht 2002).

\section{METHOD}

For a formal test of our hypotheses, we use event-history analysis. Event history is an umbrella term for a wide array of statistical techniques that are 
related to the timing of the occurrence of an event. Specifically, we use a category of event-history models that are commonly labeled as "discrete-time models," a type that is suitable for dichotomous dependent variables and data structured in the form of a subject-period file of discrete time units (Mills 2011, p. 17; see also Allison 1984). This type of model is especially appropriate when including time-varying covariates. To test our hypotheses, we perform a probit regression analysis for the occurrence of a strike in sector A (0/1) based on our sector dyad period file. Many diffusion studies have noted that such (directed) dyads are dependent on each other (Volden 2006; Boehmke 2009; Gilardi 2010). In our case, as we are estimating the occurrence of a strike in sector A, including sector-A-specific characteristics, dependence may particularly exist between dyads that share the same sector A. We address this potential dependence by applying a post hoc correction to ensure that all standard errors are robust for clustering in sector $\mathrm{A}$.

We present two series of probit models estimating the probability of a strike occurrence in sector A. As a basic model, we include the direct effects of all four types of independent variables: (1) the occurrence of a strike in sector B during the designated incubation period, (2) dyadic variables on the relations between sector $\mathrm{A}$ and sector $\mathrm{B}$, (3) monadic variables on the characteristics of sector A, and (4) non-sector-specific period variables. The main purpose of this basic model is to show whether, ceteris paribus, there is a direct effect of a strike in sector B. The main focus of this article, however, is on the extent to which this direct effect is conditioned by the similarities and interdependencies between sectors. For this purpose, a second series of models is required that focuses on interaction effects, that is, interactions between strikes in sector B, on the one hand, and the various dyadic variables on the other. Formula (4), for example, specifies the interaction between strikes in sector B and the skill-level similarity index. We estimate similar interactions with respect to the input-output index and the labor mobility index:

$$
\begin{aligned}
y_{\text {strike in sector A }}= & a+b X_{\text {strike in sector B }}+b X_{\text {skill-level similarity }} \\
& +b X_{\text {strike in sector B } \times \text { skill-level similarity }} \\
& +b X_{\text {control } 1}+\cdots+b X_{\text {control } k} .
\end{aligned}
$$

\section{RESULTS}

Table 2 shows the results of the analyses of the basic models with five different incubation periods. Our dependent variables measure the occurrence of a strike in sector A. The only difference between the five models is the measurement of the independent variable strike in sector B: whether a strike occurred in sector B in the previous week (model I), two weeks (model II), month (model III), quarter (model IV), or half year (model V). 
TABLE 2

Probit Regression of a Strike in Sector A

\begin{tabular}{|c|c|c|c|c|c|}
\hline & \multicolumn{5}{|c|}{ Basic Model } \\
\hline & Week & $\begin{array}{c}\text { Two } \\
\text { Weeks }\end{array}$ & Month & Quarter & $\begin{array}{l}\text { Half } \\
\text { Year }\end{array}$ \\
\hline \multicolumn{6}{|l|}{ Diffusion variable: } \\
\hline $\begin{array}{l}\text { Strike in sector B } \\
\text { (logged volume) }\end{array}$ & $\begin{array}{l}.003 \\
(.007)\end{array}$ & $\begin{array}{l}.002 \\
(.004)\end{array}$ & $\begin{array}{l}-.002 \\
(.005)\end{array}$ & $\begin{array}{l}-.011^{* *} \\
(.004)\end{array}$ & $\begin{array}{l}-.014 * * \\
(.004)\end{array}$ \\
\hline \multicolumn{6}{|l|}{ Sector A variables: } \\
\hline Event counter . . & $\begin{array}{l}.016 * * * \\
(.001)\end{array}$ & $\begin{array}{l}.016 * * * \\
(.001)\end{array}$ & $\begin{array}{l}.016 * * * \\
(.001)\end{array}$ & $\begin{array}{l}.016 * * * \\
(.001)\end{array}$ & $\begin{array}{l}.016 * * * \\
(.001)\end{array}$ \\
\hline $\begin{array}{l}\text { Collective agreement } \\
\text { expirations } \ldots \ldots \ldots \ldots\end{array}$ & $\begin{array}{l}.004 * * * \\
(.000)\end{array}$ & $\begin{array}{l}.004 * * * \\
(.000)\end{array}$ & $\begin{array}{l}.004 * * * \\
(.000)\end{array}$ & $\begin{array}{l}.004 * * * \\
(.000)\end{array}$ & $\begin{array}{l}.004 * * * \\
(.000)\end{array}$ \\
\hline Economic growth . . & $\begin{array}{l}.007 * * \\
(.002)\end{array}$ & $\begin{array}{l}.007 * * \\
(.002)\end{array}$ & $\begin{array}{l}.007 * * \\
(.002)\end{array}$ & $\begin{array}{l}.007 * * \\
(.002)\end{array}$ & $\begin{array}{l}.006^{* * *} \\
(.002)\end{array}$ \\
\hline Number of companies ${ }^{\mathrm{a}} \ldots$ & $\begin{array}{l}.002 \\
(.001)\end{array}$ & $\begin{array}{l}.002 \\
(.001)\end{array}$ & $\begin{array}{l}.002 \\
(.001)\end{array}$ & $\begin{array}{l}.002 \\
(.001)\end{array}$ & $\begin{array}{l}.002 \\
(.001)\end{array}$ \\
\hline$\%$ union members . . ..... & $\begin{array}{l}.010 \\
(.006)\end{array}$ & $\begin{array}{l}.010 \\
(.006)\end{array}$ & $\begin{array}{l}.010 \\
(.006)\end{array}$ & $\begin{array}{l}.010 \\
(.006)\end{array}$ & $\begin{array}{l}.010 \\
(.006)\end{array}$ \\
\hline \multicolumn{6}{|l|}{ Period variables: } \\
\hline Inflation rate $\ldots \ldots \ldots$ & $\begin{array}{c}-.068 \\
(.038)\end{array}$ & $\begin{array}{c}-.068 \\
(.038)\end{array}$ & $\begin{array}{c}-.068 \\
(.038)\end{array}$ & $\begin{array}{c}-.068 \\
(.038)\end{array}$ & $\begin{array}{c}-.067 \\
(.038)\end{array}$ \\
\hline Unemployment rate $\ldots$. & $\begin{array}{l}-.045 \\
(.025)\end{array}$ & $\begin{array}{l}-.045 \\
(.025)\end{array}$ & $\begin{array}{l}-.045 \\
(.025)\end{array}$ & $\begin{array}{l}-.044 \\
(.025)\end{array}$ & $\begin{array}{l}-.044 \\
(.025)\end{array}$ \\
\hline $\begin{array}{l}\text { Share labor party } \\
\text { cabinet } \ldots \ldots \ldots \ldots\end{array}$ & $\begin{array}{r}-.113 \\
(.183)\end{array}$ & $\begin{array}{r}-.113 \\
(.183)\end{array}$ & $\begin{aligned}-.112 \\
(.183)\end{aligned}$ & $\begin{array}{l}-.107 \\
(.182)\end{array}$ & $\begin{array}{r}-.105 \\
(.182)\end{array}$ \\
\hline \multicolumn{6}{|l|}{$\begin{array}{l}\text { Day of the week } \\
\text { (Tuesday to Friday }= \\
\text { reference) } \ldots \ldots \ldots\end{array}$} \\
\hline Weekend $\ldots \ldots \ldots \ldots$ & $\begin{array}{l}-.502 * * * \\
(.039)\end{array}$ & $\begin{array}{l}-.502 * * * \\
(.039)\end{array}$ & $\begin{array}{c}-.502 * * * \\
(.039)\end{array}$ & $\begin{array}{l}-.502 * * * \\
(.039)\end{array}$ & $\begin{array}{c}-.503 * * * \\
(.039)\end{array}$ \\
\hline Monday . . . . . . . . . . . & $\begin{array}{l}.157 * * * \\
(.046)\end{array}$ & $\begin{array}{l}.157 * * * \\
(.046)\end{array}$ & $\begin{array}{l}.157 * * * \\
(.046)\end{array}$ & $\begin{array}{l}.157 * * * \\
(.046)\end{array}$ & $\begin{array}{l}.157 * * * \\
(.046)\end{array}$ \\
\hline \multicolumn{6}{|l|}{ Dyadic variables: } \\
\hline index $($ logged $) \ldots \ldots \ldots$ & $\begin{array}{l}.013 \\
(.035)\end{array}$ & $\begin{array}{l}.013 \\
(.035)\end{array}$ & $\begin{array}{l}.014 \\
(.035)\end{array}$ & $\begin{array}{l}.013 \\
(.035)\end{array}$ & $\begin{array}{l}.013 \\
(.034)\end{array}$ \\
\hline $\begin{array}{l}\text { Input-output } \\
\text { index (logged) }\end{array}$ & $\begin{array}{r}-.010 \\
(.027)\end{array}$ & $\begin{array}{r}-.010 \\
(.027)\end{array}$ & $\begin{array}{l}-.010 \\
(.027)\end{array}$ & $\begin{array}{l}-.008 \\
(.027)\end{array}$ & $\begin{array}{r}-.008 \\
(.027)\end{array}$ \\
\hline $\begin{array}{l}\text { Labor mobility } \\
\text { index (logged) }\end{array}$ & $\begin{array}{l}.070 \\
(.041)\end{array}$ & $\begin{array}{l}.070 \\
(.041)\end{array}$ & $\begin{array}{l}.071 \\
(.041)\end{array}$ & $\begin{array}{l}.072 \\
(.041)\end{array}$ & $\begin{array}{l}.072 \\
(.041)\end{array}$ \\
\hline Intercept $\ldots \ldots \ldots \ldots$ & $\begin{array}{c}-3.025 * * * \\
(.244)\end{array}$ & $\begin{array}{c}-3.025 * * * \\
(.244)\end{array}$ & $\begin{array}{c}-3.026^{* * * *} \\
(.244)\end{array}$ & $\begin{array}{c}-3.020 * * * \\
(.245)\end{array}$ & $\begin{array}{c}-3.011^{* * * *} \\
(.243)\end{array}$ \\
\hline McFadden's $R^{2}$ & .16 & .16 & .16 & .16 & .16 \\
\hline
\end{tabular}

Note.--Robust SEs are in parentheses; clustering in sector A, $N=864,136$. McFadden's $R^{2}$ is obtained from unclustered probit regression analysis.

a Estimates are multiplied by 1,000.

$* P<.05$, two-tailed tests.

$* * P<.01$.

*** $P<.001$ 
The coefficients indicate the change in the $z$-score of the probit index given a one-unit increase in the independent variable. We present the robust standard errors in parentheses. The McFadden's $R$-squared is reported as a goodness-of-fit measure for the models.

Let us first focus on the diffusion variable. We see that the probability of a strike occurrence in sector $\mathrm{A}$ is not affected by the occurrence of a strike in sector B (measured as the logged volume) in the past week, two weeks, or month. Table 2 shows significant negative effects of a strike in sector B for incubation periods longer than a quarter and half a year. Thus, the probability of a strike in sector A decreases as the (logged) volume of a strike in sector B in the past three or six months becomes greater. While this finding may initially come as a surprise, it is plausibly a consequence of the operationalization of the occurrence of the strike in sector B variable. Strike in sector B measures the logged volume of a strike when such an event has occurred in sector B during the specified incubation period. If no strikes took place during the incubation period or when a strike in sector A occurred more recently, this variable measures zero. With longer incubation periods, it is likely that only sectors in which strikes are unusual have nonzero scores on this variable. As such, the negative relationship between strike in sector B (in the past quarter or longer) and strike in sector A appears to be an artifact caused by the measurement of strike in sector B.

Next, we included control variables for sector A characteristics to account for sectoral explanations of the occurrence of strikes. We account for the strike proneness of sectors by including an event counter variable that measures the number of strikes in the past five years in sector A. We see a strong positive significant effect from the event counter: strikes are more likely to occur in a sector that is more strike prone. Further, we include the number of expiring collective agreements in a month. It is expected that strikes are more likely to occur when the number of monthly expiring collective agreements is higher. Indeed, we find that the total number of monthly collective agreement expirations in sector A increases the likelihood of a strike. Moreover, as an indication of procyclical strike patterns, we include the economic growth in sector A, measured as the change in gross value added. We see that economic growth positively affects the occurrence of a strike. Further, the number of companies and the percentage of union members in sector A are not significantly related to the likelihood of strikes in sector A.

Next, we included non-sector-specific period variables in our models to account for suprasectoral influences on the occurrence of temporally clustered strikes. We find that strikes are not significantly related to any of the period variables in our models. Hence, strike occurrence is not affected by inflation rates and unemployment rates or by the share of cabinet portfolios held by the Dutch Labor Party PvdA. Furthermore, because strikes are less likely to occur on weekends and are more likely to begin on Mondays, we included 
dummy variables to indicate whether a strike in sector A occurred on the weekend or on a Monday. Indeed, we find that strikes are more likely to occur on Mondays than on other weekdays and are less likely to occur on weekends.

Finally, we also included dyadic characteristics. The estimates are shown only as a prelude to table 3 . We expect no direct effect from these variables because we have no theoretical expectations that strike occurrence in sector A is affected by merely the similarity or interdependency between sectors A and B. Hence, it is not surprising that we find no significant effects for the dyadic variables on strike occurrence in sector A, regardless of the demarcation of the incubation periods.

In table 3, we focus on the interactions between strikes in sector B and the dyadic characteristics. First, we expected that a sector is more likely to experience a strike if a strike occurred previously in another sector with a more similarly skilled workforce (hypothesis 1 ). We test this hypothesis in the diffusion by skill-level similarity model (panel A). The similarity in the skill levels of the workforces is measured using the logged skill-level similarity index. We find no significant main effects from the occurrence of strikes in the sectors, regardless of the demarcation of the incubation period. Further, the effects of the interactions between the occurrence of a strike in sector B and the skill-level similarity index are also not significant. These findings imply that the effect of the occurrence of a strike in sector B on the likelihood of a strike in sector A is not stronger when the skill levels of the workforces in sectors A and B are more similar. Hence, these findings do not corroborate hypothesis 1 .

Second, we expected that a strike in one sector is more likely to stimulate the occurrence of a strike in another sector when the degree of interdependence in the production or service delivery process between these sectors is higher (hypothesis 2). We test this hypothesis in the diffusion by economic interdependency model (panel B). The degree of economic interdependency is measured using the logged input-output index. We find a significant negative main effect of the (logged) volume of a strike in sector B when measuring the past six months. However, the main effect of the logged volume of a strike in sector B is not significant for the other incubation periods. Further, we find that the interaction effects between the logged volume of a strike in sector B and the input-output index are not significant for any of the incubation periods. Thus, the effect of the logged volume of a strike in sector B is not conditioned by the degree of economic interdependency. Our findings thus do not support the second hypothesis.

Third, we expected that a sector is more likely to experience a strike if a strike occurred previously in another sector with which labor market competition is stronger (hypothesis 3). We test this hypothesis in the diffusion by labor market competition model (panel C) using the logged labor 
TABLE 3

Probit Regression of a Strike in Sector A

\begin{tabular}{|c|c|c|c|c|c|}
\hline & Week & $\begin{array}{c}\text { Two } \\
\text { Weeks }\end{array}$ & Month & Quarter & $\begin{array}{l}\text { Half } \\
\text { Year }\end{array}$ \\
\hline & \multicolumn{5}{|c|}{ A. Diffusion by Skill Similarity Model } \\
\hline $\begin{array}{l}\text { Strike in sector B } \\
\quad(\text { logged volume }) \ldots\end{array}$ & $\begin{array}{l}.076 \\
(.080)\end{array}$ & $\begin{array}{l}.033 \\
(.080)\end{array}$ & $\begin{array}{l}.014 \\
(.055)\end{array}$ & $\begin{array}{l}.003 \\
(.054)\end{array}$ & $\begin{array}{l}-.009 \\
(.052)\end{array}$ \\
\hline $\begin{array}{l}\text { Skill-level similarity index } \\
\qquad \text { (logged) } \ldots \ldots \ldots \ldots\end{array}$ & $\begin{array}{l}.016 \\
(.035)\end{array}$ & $\begin{array}{l}.015 \\
(.034)\end{array}$ & $\begin{array}{l}.015 \\
(.035)\end{array}$ & $\begin{array}{l}.015 \\
(.035)\end{array}$ & $\begin{array}{l}.013 \\
(.032)\end{array}$ \\
\hline Interaction $\ldots \ldots \ldots \ldots$ & $\begin{array}{r}-.017 \\
(.018)\end{array}$ & $\begin{array}{r}-.007 \\
(.018)\end{array}$ & $\begin{array}{c}-.004 \\
(.013)\end{array}$ & $\begin{array}{c}-.003 \\
(.013)\end{array}$ & $\begin{array}{r}-.001 \\
(.012)\end{array}$ \\
\hline Intercept & $\begin{array}{c}-3.037 * * * \\
(.245)\end{array}$ & $\begin{array}{l}-3.033^{* * * *} \\
(.248)\end{array}$ & $\begin{array}{c}-3.032 * * * \\
(.251)\end{array}$ & $\begin{array}{c}-3.027 * * * \\
(.252)\end{array}$ & $\begin{array}{l}-3.014 * * * \\
(.243)\end{array}$ \\
\hline \multirow{2}{*}{ McFadden's $R^{2}$} & .16 & .16 & .16 & .16 & .16 \\
\hline & \multicolumn{5}{|c|}{ B. Diffusion by Economic Interdependency Model } \\
\hline $\begin{array}{l}\text { Strike in sector } B \\
\quad(\text { logged volume }) \ldots \ldots\end{array}$ & $\begin{array}{l}-.006 \\
(.017)\end{array}$ & $\begin{array}{l}.004 \\
(.012)\end{array}$ & $\begin{array}{l}-.006 \\
(.012)\end{array}$ & $\begin{aligned}-.013 \\
(.008)\end{aligned}$ & $\begin{array}{r}-.019 * \\
(.008)\end{array}$ \\
\hline $\begin{array}{l}\text { Input-output index } \\
\text { (logged) } \ldots \ldots\end{array}$ & $\begin{array}{c}-.011 \\
(.027)\end{array}$ & $\begin{aligned}-.010 \\
(.027)\end{aligned}$ & $\begin{aligned}-.010 \\
(.027)\end{aligned}$ & $\begin{array}{r}-.009 \\
(.028)\end{array}$ & $\begin{aligned}-.010 \\
(.028)\end{aligned}$ \\
\hline Interaction . & $\begin{array}{l}.006 \\
(.008)\end{array}$ & $\begin{array}{c}-.001 \\
(.006)\end{array}$ & $\begin{array}{l}.002 \\
(.007)\end{array}$ & $\begin{array}{l}.002 \\
(.004)\end{array}$ & $\begin{array}{l}.004 \\
(.006)\end{array}$ \\
\hline Intercept $\ldots \ldots \ldots \ldots$ & $\begin{array}{c}-3.023 * * * \\
(.245)\end{array}$ & $\begin{array}{c}-3.026 * * * \\
(.246)\end{array}$ & $\begin{array}{c}-3.024 * * * \\
(.247)\end{array}$ & $\begin{array}{c}-3.018 * * * \\
(.247)\end{array}$ & $\begin{array}{l}-3.008 * * * \\
(.243)\end{array}$ \\
\hline \multirow{2}{*}{ McFadden's $R^{2} \ldots \ldots$} & .16 & .16 & .16 & .16 & .16 \\
\hline & \multicolumn{5}{|c|}{ C. Diffusion by Labor Market Competition Model } \\
\hline $\begin{array}{l}\text { Strike in sector } B \\
\quad(\text { logged volume }) \ldots \ldots\end{array}$ & $\begin{array}{l}-.014 \\
(.010)\end{array}$ & $\begin{array}{l}-.011 \\
(.008)\end{array}$ & $\begin{array}{c}-.017 * \\
(.009)\end{array}$ & $\begin{array}{l}-.026 * * \\
(.010)\end{array}$ & $\begin{array}{l}-.031^{* * *} \\
(.010)\end{array}$ \\
\hline $\begin{array}{l}\text { Labor mobility index } \\
\qquad \text { (logged) } \ldots \ldots \ldots\end{array}$ & $\begin{array}{l}.068 \\
(.041)\end{array}$ & $\begin{array}{l}.067 \\
(.041)\end{array}$ & $\begin{array}{l}.067 \\
(.041)\end{array}$ & $\begin{array}{l}.066 \\
(.039)\end{array}$ & $\begin{array}{l}.065 \\
(.038)\end{array}$ \\
\hline Interaction $\ldots \ldots \ldots \ldots$ & $\begin{array}{l}.016^{*} \\
(.007)\end{array}$ & $\begin{array}{l}.012 * \\
(.006)\end{array}$ & $\begin{array}{l}.013^{*} \\
(.007)\end{array}$ & $\begin{array}{l}.015 \\
(.008)\end{array}$ & $\begin{array}{l}.017 \\
(.009)\end{array}$ \\
\hline Intercept $\ldots \ldots \ldots \ldots$ & $\begin{aligned}-3.021 * * * \\
(.243)\end{aligned}$ & $\begin{array}{c}-3.020 * * * \\
(.243)\end{array}$ & $\begin{aligned} &-3.018 * * * \\
&(.244)\end{aligned}$ & $\begin{array}{l}-3.009 * * * \\
(.246)\end{array}$ & $\begin{array}{c}-2.999 * * * \\
(.242)\end{array}$ \\
\hline McFadden's $R^{2} \ldots \ldots$ & .16 & .16 & .16 & .16 & .16 \\
\hline
\end{tabular}

Note.-Robust SEs are in parentheses; clustering in sector A, $N=864,136$. We also controlled for dyadic, sector A, and period variables, identical to the analyses presented in table 2 . For graphic purposes, we present only the main effects and interaction effects. McFadden's $R^{2}$ is obtained from unclustered probit regression analysis.

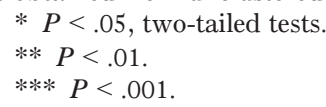


mobility index as an indicator for competition. Here, we find that the main effect of (the logged volume of) a strike in sector B is negative but significant only when this strike occurred in the past month or earlier. The effect of the interaction between (the logged volume of) a strike in sector B and the log of the labor mobility index is positive and significant. However, it loses its statistical significance when examining periods of a quarter of a year and longer.

The significant interaction effects appear to be in line with the expectations of the third hypothesis. The estimates in the probit regression analyses, especially as compared to logit analyses, can be difficult to interpret. First, they present the estimated effects of covariates on a latent, nonobserved variable. Second, they indicate a change in the z-score rather than a change in odds. To facilitate interpretation of the estimated interaction effect between the logged labor mobility index and the logged volume of a strike in sector B, we calculated the predicted probability of a strike in sector A for different values of the logged volume of a strike in sector B while keeping the labor mobility index at the minimum and maximum values. The marginal effects of the other covariates are averaged. The predicted probabilities are presented in figure 3. We excluded the figures for the interaction effects with (the logged volume of) a strike in sector B in the past quarter and half year because we found no significant interaction effects with these particular dependent variables.

Figure 3 shows that the predicted probability of a strike in a sector is rather small: the predicted probability of a strike's occurrence on a given day is lower than .018. This finding is not surprising because the Netherlands is known for its relatively small number of strikes. Nevertheless, the predicted probability strongly depends on the degree of intersectoral labor mobility and the volume of the strike in sector B. When we compare the minimum and maximum observed values of the labor mobility index, we see that the predicted probability of the occurrence of a strike in sector $\mathrm{A}$ is quite similar when there is no strike in sector B during the designated incubation period: for example, we find predicted probabilities of .005 (low labor mobility) and .008 (high labor mobility) when there were strikes in sector B during the past week. The predicted probabilities for sectors with low labor mobility and high labor mobility diverge as the volume of the strike in sector B increases. The predicted probability for sectors with low labor mobility drops to .003. The predicted probability for sectors with high labor mobility rises to .173 , more than twice the predicted probability of a strike in sector $\mathrm{A}$ when there is no strike in sector B. The graphs for the two-week incubation period and the one-month incubation period present a similar picture. Overall, these findings indicate that for incubation periods up to one month, a strike in one sector is indeed more likely to stimulate the occurrence of a 
strike in another sector when the degree of intersectoral labor mobility between these sectors is higher, as predicted by the third hypothesis.

\section{CONCLUSIONS}

The current study was designed to determine the extent to which strikes diffuse across sectors and the extent to which the diffusion of strikes across sectors can be explained by similarities and interdependencies between sectors. For this purpose, using a series of discrete-time event-history models, we examined a new, temporally disaggregated, and dyadic database on strikes in the Netherlands for the 1995-2007 period combined with relevant time-varying and relational variables on Dutch sectors. This approach enabled us to investigate three conditions under which industrial action may propagate from one sector to another. Building on theories of protest diffusion, we distinguish two mechanisms through which diffusion takes place: diffusion by learning and diffusion by adaptation. Diffusion by learning is more likely when sectors are more similar. We therefore expected that strikes will be more likely to spread between two sectors when these sectors are more similar in the occupational skill-level composition of their workforce. Diffusion by adaptation is more likely when sectors are economically interdependent. Therefore, we expected that strikes will be more likely to diffuse when sectors exchange more goods and services and through wage interdependencies created by labor market competition between sectors.

Building on previous studies observing that strikes are not isolated events, the major contribution of this study is its demonstration that strikes may spread across sectors of economic activity. However, this study also shows that this diffusion of strikes does not occur unconditionally but that this process is likely to be driven by market competition between sectors (indicated by the degree of intersectoral labor mobility). We hypothesized that strike diffusion by labor market competition may occur through adaptation to changes in labor market conditions caused by strikes elsewhere. We find that this effect appears between one week and one month after the beginning of the original strike.

Although, theoretically, adaptation can be distinguished from diffusion by learning, it proved much harder to separate these mechanisms empirically. With labor mobility as an indicator for labor market competition, we assumed that employees transfer more easily among sectors that require similar skills. However, labor mobility may be an indicator not only of labor market competition but also of workforce similarities, which we assumed enhances learning. Moreover, learning by information spillover, for example, about work practices and employment conditions elsewhere, may occur via labor mobility (Görg and Strobl 2005). Considering the institutional 

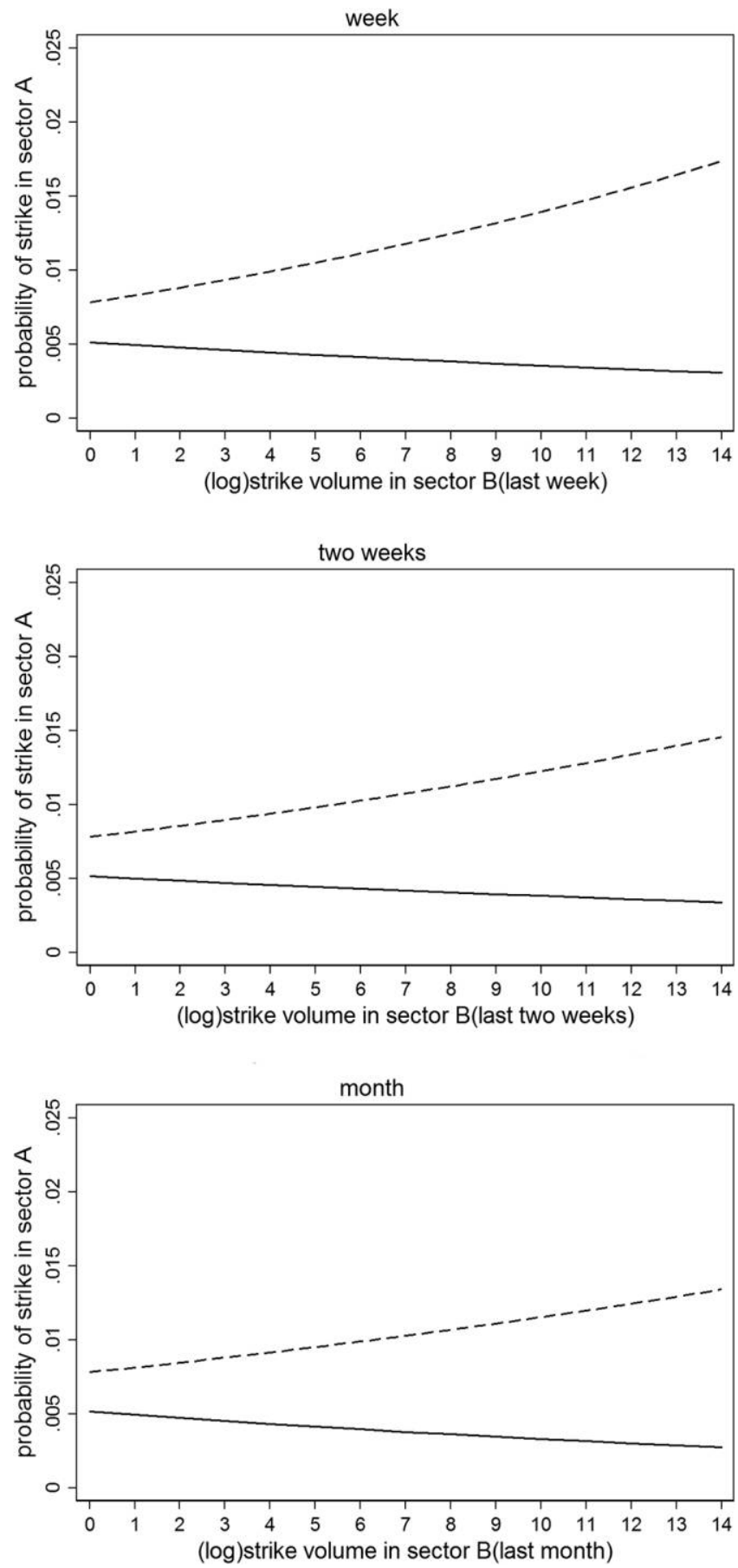

FIG. 3.-Interaction between strike volume in sector B in the previous period (week, two weeks, month) and labor mobility (between sector A and B) on the predicted probability of a strike in sector A. Solid line indicates low labor mobility; broken line indicates high labor mobility. 
context of the Dutch labor market-labor law prescribes a term of notice of at least one month for employees as well as for employers-adaptation through wage competition would require a longer incubation time for strikes to diffuse. Our finding that diffusion occurs within one week to one month therefore cannot rule out that strike diffusion is driven by learning rather than adaptation because labor mobility may also indicate workforce similarities. However, learning via similarity in workforce skill levels did not yield significant results. It appeared that the likelihood of strike diffusion between two sectors does not increase when these sectors have more in common with respect to the skill level composition of their workforces. It may be the case that when employees learn from similar others, they do not use general skill levels as a reference for comparison but rather compare themselves with those with equivalent positions in the labor market. In this respect, labor mobility may capture a more specific occupational similarity that is more relevant for the comparison of employment conditions.

With respect to economic interdependency, our findings indicate that the exchange of goods and services has no effect on strike diffusion. The notion that flows of capital may function as a channel of conflict diffusion in the industrial relations arena is therefore not corroborated in this study. That we find no support for diffusion via financial interdependency implies that the disruptive potential of strikes for other sectors should not be overestimated. This is not to say that strikes do not cause any or even severe disruptions in the production process elsewhere. It merely indicates that such disruptions do not lead to new labor conflicts.

Our study on the intersectoral diffusion of strikes in the Netherlands constitutes a conservative test of the conditions under which strikes diffuse. If labor mobility stimulates strike diffusion, it is plausible that this effect also occurs within sectors because intrasectoral labor mobility is often even stronger than intersectoral mobility (Van den Berg and Peltzer 2011). In addition, the Dutch context constitutes a conservative case regarding the generalization of our findings to other countries. If the sector-to-sector diffusion of strikes occurs in a low-strike-frequency country such as the Netherlands, we expect this phenomenon to be even more pronounced in more strike-prone countries.

Finally, there are several limitations to this study that need to be considered. One issue that should be acknowledged concerns the demarcation of economic sectors. Obviously, whether the clustering of strikes is considered an inter- or intrasectoral phenomenon is dependent on the definition of what constitutes a sector. In this study, we demarcated sectors on the basis of one-digit SBI classifications. A more fine-grained demarcation of economic activities based on industries or branches (e.g., two- or three-digit SBI codes) would have enabled us to test our hypotheses in a more stringent manner. However, it appeared infeasible to conduct the current analyses 
at a lower level of sector aggregation. Essential sector characteristics, including relational information between sectors such as statistics on labor mobility, are not available for more detailed classifications of economic activity.

Another limitation is that the current study did not address the issue of geographical proximity (see, e.g., Shorter and Tilly 1974). As explained earlier, the available data and the research design do not allow the inclusion of any measure of spatial proximity. Of course, geographic proximity is related to the mechanisms of diffusion examined in this study. Labor mobility, for example, may be more likely between two nearby jobs, and also the transfer of goods and services may often occur between firms that are located relatively close to each other. This is not to say, however, that geographical nearness would necessarily interpret the effect of intersectoral labor mobility on strike diffusion. More likely, quite the contrary might be true, as geographic proximity does not explain the underlying diffusion mechanism (Karch 2007; Füglister 2011). "Neighbor effects" might occur as a result of learning (e.g., by information spillover between two nearby actors) as well as adaptation (e.g., by competition). Hence, following Karch, we may expect that "even when proximity has a statistically significant effect on diffusion, the source of this relationship remains open to interpretation" (2007, p. 58).

Moreover, in a study of the Netherlands, the absence of geographical variables may be less problematic than it might be for larger countries. Lehr, Akkerman, and Torenvlied (2015) show that during collective bargaining in the Netherlands, negotiators are hardly influenced by geographical dynamics, such as local employment developments or other negotiations in the same region. For one, since it is a small country, city-to-city distances in the Netherlands are all relatively short and travelable within a few hours. Many Dutch employees do not live in the same city in which they work and commute to other cities on a daily basis. Strikes, especially in large companies, may therefore already involve workers from different cities. Moreover, most relevant media have national coverage, which allows news about a strike to spread easily beyond the immediate environment.

The current study also did not address strike outcomes. A central hypothesis in Conell and Cohn's (1995) work on French coal mine strikes was that successful strikes stimulate higher imitation rates than failed strikes. Actions that end with the employer (largely or partially) meeting the demands of workers should transmit more relevant information on the favorability of industrial action. Our study was limited by a lack of consistent information on the outcomes of strikes. Although the SIN database includes information on wins and losses on strike actions, this type of information is not available for approximately $40 \%$ of all strike events in the period under study.

We suggest that the diffusion of strikes should be investigated further in future studies. More research is needed to test the claim that flows of information along channels between sectors influence the incidence of strikes. 


\section{Diffusion of Strikes}

Future research could explore whether information on strikes also spreads across channels other than via labor mobility. For one, if conducted in larger countries, we recommend that future studies assess the importance of geographic proximity for the transmission of information. Moreover, the current analysis was restricted not only to the Netherlands but also to the period 19952007, that is, after the economic crisis of the 1980s and before the crisis of 2008 onward. For future research, it would be interesting to assess the diffusion of strikes during a time of recession, for instance, because the disruptive power of strikes may be altered in times of economic hardship. Finally, an actorcentered focus on employees or employers, which would require data at lower levels of aggregation, may allow us to directly test the mechanisms underlying diffusion.

\section{APPENDIX}

Matrices for Dyadic Variables

TABLE A1

Mean Skill-Level Similarity Index (1995-2007) per Sector Pair

\begin{tabular}{|c|c|c|c|c|c|c|c|c|c|c|c|c|c|}
\hline \multirow[b]{2}{*}{ SECTOR A } & \multicolumn{13}{|c|}{ Sector B } \\
\hline & 1 & 2 & 3 & 4 & 5 & 6 & 7 & 8 & 9 & 10 & 11 & 12 & 13 \\
\hline 1. & $\ldots$ & & & & & & & & & & & & \\
\hline 2. & 64.3 & & & & & & & & & & & & \\
\hline 3. & 79.6 & 71.7 & & & & & & & & & & & \\
\hline 4. & 75.6 & 85.5 & 76.7 & & & & & & & & & & \\
\hline 5. & 90.9 & 67.8 & 84.0 & 74.8 & & & & & & & & & \\
\hline 6. & 82.4 & 65.7 & 92.4 & 70.8 & 88.0 & & & & & & & & \\
\hline 7. & 75.6 & 48.8 & 76.7 & 53.6 & 78.4 & 82.8 & & & & & & & \\
\hline 8. & 77.0 & 61.4 & 86.0 & 66.1 & 84.8 & 91.3 & 86.4 & & & & & & \\
\hline 9. & 64.4 & 88.0 & 73.4 & 86.2 & 69.1 & 67.2 & 50.0 & 62.6 & & & & & \\
\hline 10. & 51.2 & 80.2 & 70.0 & 72.5 & 55.7 & 65.8 & 55.7 & 65.9 & 81.9 & & & & \\
\hline 11. & 64.1 & 87.1 & 78.4 & 82.2 & 69.7 & 73.2 & 56.3 & 68.9 & 85.0 & 84.0 & & & \\
\hline 12. & 20.8 & 56.0 & 35.1 & 43.3 & 26.4 & 31.2 & 21.1 & 32.6 & 55.6 & 65.1 & 56.7 & & \\
\hline 13. & 68.0 & 89.4 & 78.8 & 88.0 & 73.2 & 72.7 & 55.5 & 68.0 & 88.8 & 82.2 & 93.0 & 52.7 & \\
\hline 14. & 65.0 & 81.3 & 81.8 & 81.7 & 69.4 & 77.0 & 61.8 & 74.0 & 87.2 & 86.3 & 88.4 & 53.3 & 87.5 \\
\hline
\end{tabular}

Note.-Sectors: 1 = agriculture, hunting, forestry (A), and fishery (B); 2 = mining and quarrying (C); 3 = manufacturing (D); 4 = electricity, gas, and water supply (E); 5 = construction $(\mathrm{F}) ; 6=$ wholesale and retail trade $(\mathrm{G}) ; 7=$ hotels and restaurants $(\mathrm{H}) ; 8=$ transport, storage, and communication (I); 9 = financial intermediation $(\mathrm{J}) ; 10=$ real estate, renting, and business activities $(\mathrm{K}) ; 11=$ public administration and defense $(\mathrm{L}) ; 12=$ education $(\mathbf{M}) ; 13=$ health and social work $(\mathrm{N}) ; 14=$ other community, social-personal service $(\mathrm{O})$. Letters in parentheses are SBI-93 sector classifications. 
TABLE A2

Mean Input-Output Index (1995-2007) Per Sector Pair

\begin{tabular}{|c|c|c|c|c|c|c|c|c|c|c|c|c|c|}
\hline \multirow[b]{2}{*}{ Sector A } & \multicolumn{13}{|c|}{ Sector B } \\
\hline & 1 & 2 & 3 & 4 & 5 & 6 & 7 & 8 & 9 & 10 & 11 & 12 & 13 \\
\hline 1. & $\ldots$ & & & & & & & & & & & & \\
\hline 2. & .11 & & & & & & & & & & & & \\
\hline 3. & 14.94 & 3.38 & & & & & & & & & & & \\
\hline 4. & 5.08 & 24.06 & 4.35 & & & & & & & & & & \\
\hline 5. & .51 & .85 & 9.49 & .80 & & & & & & & & & \\
\hline 6. & .82 & .23 & 7.31 & 4.26 & 1.57 & & & & & & & & \\
\hline 7. & .84 & .12 & 3.38 & 2.44 & .41 & 3.07 & & & & & & & \\
\hline 8. & .93 & 1.23 & 5.13 & 1.54 & 2.67 & 9.26 & 5.27 & & & & & & \\
\hline 9. & 1.75 & .55 & 3.53 & 1.17 & 2.32 & 7.91 & 2.78 & 7.21 & & & & & \\
\hline 10. & 1.22 & .51 & 13.04 & 3.17 & 10.15 & 17.00 & 3.08 & 10.50 & 12.03 & & & & \\
\hline 11. & .66 & .15 & 1.90 & 2.83 & 7.15 & 1.27 & 2.31 & 7.74 & 3.30 & 3.75 & & & \\
\hline 12. & .11 & .14 & 1.35 & 1.91 & 1.06 & 1.53 & 1.08 & 2.15 & .83 & 2.04 & 7.24 & & \\
\hline 13. & 2.13 & .06 & 1.80 & 2.65 & 1.28 & 1.01 & 2.94 & 3.19 & 2.40 & 3.10 & 1.76 & 1.76 & \\
\hline 14. & 1.74 & .22 & 4.22 & 2.68 & 2.53 & 4.66 & 3.37 & 3.87 & 3.19 & 5.77 & .83 & 1.33 & 3.59 \\
\hline
\end{tabular}

Note.- Sectors: 1 = agriculture, hunting, forestry (A), and fishery (B); 2 = mining and quarrying (C); 3 = manufacturing (D); 4 = electricity, gas, and water supply (E); 5 = construction $(\mathrm{F}) ; 6=$ wholesale and retail trade $(\mathrm{G}) ; 7=$ hotels and restaurants $(\mathrm{H}) ; 8=$ transport, storage, and communication $(\mathrm{I}) ; 9=$ financial intermediation $(\mathrm{J}) ; 10=$ real estate, renting, and business activities $(\mathrm{K}) ; 11=$ public administration and defense $(\mathrm{L}) ; 12=$ education $(\mathbf{M}) ; 13=$ health and social work $(\mathrm{N}) ; 14=$ other community, social-personal service $(\mathrm{O})$. Letters in parentheses are SBI-93 sector classifications.

TABLE A3

Mean Labor Mobility Index (1995-2007) Per Sector Pair

\begin{tabular}{|c|c|c|c|c|c|c|c|c|c|c|c|c|c|}
\hline \multirow[b]{2}{*}{ SECTOR A } & \multicolumn{13}{|c|}{ Sector B } \\
\hline & 1 & 2 & 3 & 4 & 5 & 6 & 7 & 8 & 9 & 10 & 11 & 12 & 13 \\
\hline 1. & $\ldots$ & & & & & & & & & & & & \\
\hline 2. & .24 & & & & & & & & & & & & \\
\hline 3. & .79 & .24 & & & & & & & & & & & \\
\hline 4. & .32 & .23 & .35 & & & & & & & & & & \\
\hline 5. & .77 & .25 & 3.45 & .36 & & & & & & & & & \\
\hline 6. & .88 & .24 & 6.65 & .35 & 2.74 & & & & & & & & \\
\hline 7. & .66 & .25 & 1.38 & .37 & .94 & 3.46 & & & & & & & \\
\hline 8. & .85 & .25 & 2.58 & .38 & 1.86 & 4.93 & 1.69 & & & & & & \\
\hline 9. & .73 & .25 & 1.23 & .38 & 1.07 & 1.71 & .86 & 1.53 & & & & & \\
\hline 10. & 1.49 & .29 & 5.92 & .51 & 3.31 & 6.81 & 2.48 & 4.80 & 5.46 & & & & \\
\hline 11. & .84 & .25 & 1.75 & .38 & 1.52 & 2.01 & 1.02 & 1.83 & 1.48 & 5.42 & & & \\
\hline 12. & .67 & .24 & 1.27 & .34 & 1.11 & 1.49 & .84 & 1.21 & .95 & 2.71 & 1.45 & & \\
\hline 13. & .79 & .24 & 1.91 & .35 & 1.49 & 2.61 & 1.45 & 1.71 & 10.16 & 3.35 & 2.05 & 2.24 & \\
\hline 14. & .84 & .26 & 1.55 & .40 & 1.28 & 2.46 & 1.26 & 1.75 & 1.11 & 3.19 & 1.67 & 1.15 & 1.62 \\
\hline
\end{tabular}

Note.-Sectors: 1 = agriculture, hunting, forestry (A), and fishery $(\mathrm{B}) ; 2=$ mining and quarrying $(\mathrm{C}) ; 3=$ manufacturing $(\mathrm{D}) ; 4=$ electricity, gas, and water supply $(\mathrm{E}) ; 5=$ construction $(\mathrm{F}) ; 6=$ wholesale and retail trade $(\mathrm{G}) ; 7=$ hotels and restaurants $(\mathrm{H}) ; 8=$ transport, storage, and communication $(\mathrm{I}) ; 9=$ financial intermediation $(\mathrm{J}) ; 10=$ real estate, renting, and business activities $(\mathrm{K}) ; 11=$ public administration and defense $(\mathrm{L}) ; 12=$ education $(\mathrm{M}) ; 13=$ health and social work $(\mathrm{N}) ; 14$ = other community, social-personal service $(\mathrm{O})$. Letters in parentheses are SBI-93 sector classifications. 


\section{REFERENCES}

Agrawal, Ajay, Devesh Kapur, and John McHale. 2008. "How Do Spatial and Social Proximity Influence Knowledge Flows? Evidence from Patent Data." Journal of Urban Economics 64 (2): 258-69.

Aklalouch, Ali. 2014. "Vonk slaat over van schoonmakers naar VU'ers." Abvakabo FNV Ledenblad (4-2014, 27/46).

Allison, Paul. 1984. Event History Analysis: Regression for Longitudinal Event Data. Beverly Hills, Calif.: Sage.

Andrews, Kenneth T., and Michael Biggs. 2006. "The Dynamics of Protest Diffusion: Movement Organizations, Social Networks, and News Media in the 1960 Sit-Ins." American Sociological Revierw 71 (5): 752-77.

Beck, Nathaniel, Jonathan N. Katz, and Richard Tucker. 1998. "Taking Time Seriously: Time-Series-Cross-Section Analysis with a Binary Dependent Variable." American Journal of Political Science 42 (4): 1260-88.

Berry, F. S., and W. D. Berry. 1990. "State Lottery Adoptions as Policy Innovations: An Event History Analysis." American Political Science Review 84:395-415.

Biggs, Michael. 2005. "Strikes as Forest Fires: Chicago and Paris in the Late Nineteenth Century." American Journal of Sociology 110 (6): 1684-1714.

. 2013. "How Repertoires Evolve: The Diffusion of Suicide Protest in the Twentieth Century." Mobilization: An International Quarterly 18 (4): 407-28.

Boehmke, Frederick J. 2009. "Policy Emulation or Policy Convergence? Potential Ambiguities in the Dyadic Event History Approach to State Policy Emulation." Journal of Politics 71 (3): 1125-40.

Brandl, Bernd, and Franz Traxler. 2010. "Labour Conflicts: A Cross-National Analysis of Economic and Institutional Determinants, 1971-2002." European Sociological Review 26 (5): 519-40.

Braun, Robert, and Ruud Koopmans. 2010. "The Diffusion of Ethnic Violence in Germany: The Role of Social Similarity." European Sociological Review 26 (1): 111-23.

Buhaug, Halvard, and Kristian S. Gleditsch. 2008. "Contagion or Confusion? Why Conflicts Cluster in Space." International Studies Quarterlv 52 (2): 215-33.

Burt, Ronald S. 1983. Corporate Profits and Cooptation: Networks of Market Constraints and Directorate Ties in the American Economy. New York: Academic Press.

Centola, Damon, and Michael Macy. 2007. "Complex Contagions and the Weakness of Long Ties." American Journal of Sociologv 113 (3): 702-34.

Conell, Carol, and Samuel Cohn. 1995. "Learning from Other People's Actions: Environmental Variation and Diffusion in French Coal Mining Strikes, 1890-1935." American Journal of Sociology 101 (2): 366-403.

Cörvers, Frank, and Hans Heijke. 2004. "Forecasting the Labour Market by Occupation and Education: Some Key Issues." Researchcentrum voor Onderwijs en Arbeidsmarkt, Faculteit der Economische Wetenschappen en Bedrijfskunde, Universiteit Maastricht.

Cronin, James E. 1979. Industrial Conflict in Modern Britain. London: Rowman \& Littlefield.

Diani, Mario. 2004. "Networks and Participation." Pp. 339-59 in The Blackwell Companion to Social Movements, edited by David A. Snow, Sarah A. Soule, and Hanspeter Kriesi. Malden, Mass.: Blackwell.

Elkins, Zachery, and Beth Simmons. 2005. "On Waves, Clusters, and Diffusion: A Conceptual Framework." Annals of the American Academv of Political and Social Science 598 (1): 33-51.

Franzosi, Roberto. 1995. The Puzzle of Strikes: Class and State Strategies in Postwar Italy. Cambridge: Cambridge University Press. 


\section{American Journal of Sociology}

Füglister, Katharina. 2011. "Cantons as Policy Laboratories of the Federal State? The Diffusion of Health Insurance Subsidy Policies among the Swiss Cantons.” Doctoral dissertation. University of Zürich.

Gilardi, Fabrizio. 2010. "Who Learns from What in Policy Diffusion Processes?" American Journal of Political Science 54 (3): 650-66.

Givan, Rebecca K., Kenneth M. Roberts, and Sarah A. Soule. 2010. The Diffusion of Social Movements: Actors, Mechanisms, and Political Effects. New York: Cambridge University Press.

Gleditsch, Kristian S. 2007. "Transnational Dimensions of Civil War.” Journal of Peace Research 44 (3): 293-309.

Görg, Holger, and Eric Strobl. 2005. "Spillovers from Foreign Firms through Worker Mobility: An Empirical Investigation.” Scandinavian Journal of Economics 107 (4): 693-709.

Gould, Roger V. 1991. "Multiple Networks and Mobilization in the Paris Commune, 1871." American Sociological Review 56 (3): 716-29.

Granovetter, Mark S. 1979. "The Theory-Gap in Social Network Analysis.” Pp. 501-18 in Perspectives on Social Network Research, edited by P. W. Holland and S. Leinhardt. New York: Academic Press.

Hedström, Peter. 1994. "Contagious Collectivities: On the Spatial Diffusion of Swedish Trade Unions." American Journal of Sociology 99 (5): 1157-79.

Hegre, Havard, Tanja Ellingsen, Scotts Gates, and Nils P. Gleditsch. 2001. "Toward a Democratic Civil Peace? Democracy, Political Change, and Civil War, 1816-1992." American Political Science Review 95 (1): 33-48.

Holden, Robert T. 1986. "The Contagiousness of Aircraft Hijacking.” American Journal of Sociology 91:874-904.

Jansen, Giedo. 2014. "Effects of Union Organization on Strike Incidence in EU Companies." Industrial and Labor Relations Review 67 (1): 60-85.

Jung, Jai. 2010. "Disentangling Protest Cycles: An Event-History Analysis of New Social Movements in Western Europe." Mobilization: An International Quarterly 15 (1): 2544.

Kalmijn, Matthijs. 1998. "Intermarriage and Homogamy: Causes, Patterns, Trends." Annual Review of Sociology 24:395-421.

Karch, Andrew. 2007. "Emerging Issues and Future Directions in State Policy Diffusion Research." State Politics and Policv Ouarterlv 7 (1): 54-80.

Kaufman, Bruce E. 1982. "The Determinants of Strikes in the United States, 1900-1977." Industrial and Labor Relations Review 35:473-90.

. 2007. "What Unions Do: Insights from Economic Theory." Pp. 12-45 in What Do Unions Do? A Twenty-Year Perspective, edited by James T. Bennett and Bruce E. Kaufman. New Brunswick, N.J.: Transaction.

Kaufman, Roger T. 1984. "On Wage Stickiness in Britain's Competitive Sector.” British Journal of Industrial Relations 22 (1): 101-12.

Kaufman, Roger T., and Geoffrey Woglom. 1984. "The Effects of Expectations on Union Wages." American Economic Review 74:418-32.

Koopmans, Ruud, and Dieter Rucht. 2002. "Protest Event Analysis." Pp. 231-59 in Methods of Social Movement Research, edited by Bert Klandermans and Suzanne Staggenborg. Minneapolis: University of Minnesota Press.

Korpi, Walter, and Michael Shalev. 1979. "Strikes, Industrial Relations and Class Conflict in Capitalist Societies." British Journal of Sociology 30:164-87.

Krugman, Paul. 2015. "Walmart's Visible Hand.” New York Times, March 2. http://nyti .ms/18DFTRd.

Lehr, Alex, Agnes Akkerman, and René Torenvlied. 2014. "Spillover and Conflict in Collective Bargaining: Evidence from a Survey of Dutch Union and Firm Negotiators." Work, Employment and Society. DOI:0950017014542123. 
2015. "The Influence of External Information on Collective Bargaining: Survey Evidence of Union and Firm Negotiators in the Netherlands." Relations Industrielles Industrial Relations 70 (2): 327-35.

Lim, Chaeyoon. 2008. "Social Networks and Political Participation: How Do Networks Matter?" Social Forces 87 (2): 961-82.

Marsden, Peter V. 1988. "Homogeneity in Confiding Relations." Social Networks 10 (1): 57-76.

Marsden, Peter V., and Noah E. Friedkin. 1993. "Network Studies of Social Influence." Sociological Methods and Research 22 (1): 127-51.

McAdam, Doug. 1995. "Initiator' and 'Spin-Off' Movements: Diffusion Processes in Protest Cycles." Pp. 217-39 in Repertoires and Cycles of Collective Action, edited by Mark Traugott. Durham, N.C.: Duke University Press.

McAdam, Doug, and Dieter Rucht. 1993. "The Cross-National Diffusion of Movement Ideas." Annals of the American Academy of Political and Social Science 528 (1): 5674.

McAdam, Doug, Sidney Tarrow, and Charles Tilly. 2001. Dynamics of Contention. New York: Cambridge University Press.

McPherson, Miller, Lynn Smith-Lovin, and James M. Cook. 2001. "Birds of a Feather: Homophily in Social Networks." Annual Review of Sociology 27:415-44.

Mills, Melinda. 2011. Introducing Survival and Event History Analysis. London: Sage.

Mizruchi, Mark S., and Thomas Koenig. 1986. "Economic Sources of Corporate Political Consenses: An Examination of Interindustry Relations." American Sociological Review 51:482-91.

Morath, Eric. 2015. "What Wal-Mart's Pay Raise May Mean for Other Workers.” Wall Street Journal, February 19. http://blogs.wsj.com/economics/2015/02/19/what-wal-marts -pay-raise-may-mean-for-other-workers.

Myers, Daniel J. 1997. "Racial Rioting in the 1960s: An Event History Analysis of Local Conditions." American Sociological Review 62:94-112.

2000. "The Diffusion of Collective Violence: Infectiousness, Susceptibility, and Mass Media Networks.” American Journal of Sociology 106 (1): 173-208.

2010. "Violent Protest and Heterogeneous Diffusion Processes: The Spread of US Racial Rioting from 1964 to 1971.” Mobilization: An International Quarterly 15 (3): 289-321.

Neate, Rupert. 2015. "Walmart Minimum Wage to Keep Staff Rise Piles Pressure on Rivals." Guardian, February 28. http://gu.com/p/467ym/sbl.

Olzak, Susan. 1989. "Analysis of Events in the Study of Collective Action." Annual Review of Sociology 15:119-41.

Olzak, Susan, Maya Beasley, and Johan Olivier. 2002. "The Impact of State Reforms on Protest against Apartheid in South Africa.” Mobilization: An International Quarterly 8 (1): 27-50.

Passy, Florence, and Marco Giugni. 2001. "Social Networks and Individual Perceptions: Explaining Differential Participation in Social Movements." Sociological Forum 16 (1): 123-53.

Perrone, Lucas, Erik Olin Wright, and Larry J. Griffin. 1984. "Positional Power, Strikes and Wages." American Sociological Review 49 (3): 412-26.

Piazza, James A. 2005. "Globalizing Quiescence: Globalization, Union Density and Strikes in 15 Industrialized Countries." Economic and Industrial Democracy 26 (2): 289-314.

Rogers, Everett M. 1995. Diffusion of Innovations, 4th ed. New York: Free Press.

Schneider, Mark, Paul Teske, Christine Roch, and Melissa Marschall. 1997. "Networks to Nowhere: Segregation and Stratification in Networks of Information about Schools." American Journal of Political Science 41 (4): 1201-23.

Schutte, Sebastian, and Nils B. Weidmann. 2011. "Diffusion Patterns of Violence in Civil Wars." Political Geography 30 (3): 143-52. 


\section{American Journal of Sociology}

Shalev, Michael. 1980. "Trade Unionism and Economic Analysis: The Case of Industrial Conflict." Journal of Labor Research 1 (1): 133-73.

Shorter, Edward, and Charles Tilly. 1974. Strikes in France, 1830-1968. Cambridge: Cambridge University Press.

Sluiter, Roderick. 2012. The Diffusion of Morality Policies among Western European Countries between 1960 and 2010: A Comparison of the Temporal and Spatial Diffusion Patterns of Six Morality and Eleven Non-morality Policies. Nijmegen: Radboud University/ICS Dissertation Series.

Snyder, David. 1975. "Institutional Setting and Industrial Conflict: Comparative Analyses of France, Italy and the United States." American Sociological Review 40 (3): 25978.

Soule, Sarah A. 1997. "The Student Divestment Movement in the United States and Tactical Diffusion: The Shantytown Protest." Social Forces 75 (3): 855-82.

. 1999. "The Diffusion of an Unsuccessful Innovation." Annals of the American Academy of Political and Social Science 566 (1): 120-31.

Statistics Netherlands. 2001. Standaard Beroepsclassificatie 1992. Den Haag/Heerlen: CBS.

2013. Bedrijuen naar Aantal Werkzame Personen en Economische Activiteit: Statline Archief. Den Haag/Heerlen: CBS.

Strang, David. 1991. "Adding Social Structure to Diffusion Models: An Event History Framework." Sociological Methods and Research 19 (3): 324-53.

Strang, David, and John W. Meyer. 1993. "Institutional Conditions for Diffusion." Theorv and Societv 22 (4): 487-511.

Strang, David, and Sarah A. Soule. 1998. "Diffusion in Organizations and Social Movements: From Hybrid Corn to Poison Pills." Annual Review of Sociology 24:26590.

Strang, David, and Nancy B. Tuma. 1993. "Spatial and Temporal Heterogeneity in Diffusion." American Journal of Sociology 99 (3): 614-39.

Tabuchi, Hiroko, and Steven Greenhouse. 2014. "Walmart Workers Demand \$15 Wage in Several Protests." New York Times, October 16. http://nyti.ms/1yIH8Z9.

Van Cruchten, Jo, Rob Kuijpers, and Sjaak Van der Velden. 2006. "Werkstakingen 1900-2004." Sociaaleconomische Trends 2006 (1): 29-37.

Vandaele, Kurt. 2011. Sustaining or Abandoning "Social Peace"? Strike Development and Trends in Europe since the 1990s. Brussels: European Trade Union Institute.

Van den Berg, Han, and Nathalie Peltzer. 2011. "Arbeidsmarktdynamiek 2001-2008." Sociaaleconomische Trends 2011 (2): 63-75.

Van der Bie, Ronald. 2001. "Historische Arbeidersstrijd (Recensie)." CBS Index 5:30-31.

Van der Velden, Sjaak. 2000. Stakingen in Nederland: Arbeidersstrijd, 1830-1995. Amsterdam: Stichting beheer ISSG/NIWI.

- 2007. "Strikes behind the Dykes." Pp. 298-320 in Strikes around the World, 1968-2005: Case-Studies of 15 Countries, edited by Sjaak Van der Velden, Heiner Dribbusch, Dave Lyddon, and Kurt Vandaele. Amsterdam: Aksant.

Visser, Jelle. 1998. "The Netherlands: The Return of Responsive Corporatism." Pp. 283314 in Changing Industrial Relations in Europe, edited by Anthony Ferner and Richard Hyman. Oxford: Blackwell.

Volden, Craig. 2006. "States as Policy Laboratories: Emulating Success in the Children's Health Insurance Program.” American Journal of Political Science 50 (2): 294-312.

Wang, Dan J., and Sarah A. Soule. 2012. "Social Movement Organizational Collaboration: Networks of Learning and the Diffusion of Protest Tactics, 1960-1995." American Journal of Sociology 117 (6): 1674-1722. 